\title{
LIPID MEDIATORS IN INFLAMMATION
}

\section{Melanie Bennett and Derek W Gilroy}

DWG: Centre for Clinical Pharmacology and Therapeutics, Division of Medicine, 5 University Street, University College London, London WC1E 6JJ, UK.

MB: Roche Products Limited, Hexagon Place, 6 Falcon Way, Shire Park, Welwyn Garden City, AL7 1TW

Address correspondence to DWGilroy. E-mail d.gilroy@ucl.ac.uk; fax +020-7679-6351

KEYWORDS: arachidonic acid, polyunsaturated fatty acids, eicosanoids, prostanoids, leukotrienes, lipoxins, epoxyeicosatrienoic acids, docosahexaenoic acid, resolvins, protectins, maresins, cytochrome p450. 


\section{ABSTRACT}

Lipids are potent signaling molecules that regulate a multitude of cellular responses including cell growth and death, and inflammation/infection, via receptor-mediated pathways. Derived from polyunsaturated fatty acids (PUFAs), such as arachidonic acid (AA), eicosapentaenoic acid (EPA) and docosahexaenoic acid (DHA), each lipid displays unique properties, thus making their role in inflammation distinct from that of other lipids derived from the same PUFA. This diversity arises from their synthesis, which occurs via discrete enzymatic pathways and because they elicit responses via different receptors. This chapter will collate the bioactive lipid research to date and summarise the major pathways involved in their biosynthesis and role in inflammation. Specifically, lipids derived from AA (prostanoids, leukotrienes, 5-oxo-6,8,11,14-eicosatetraenoic acid, lipoxins and epoxyeicosatrienoic acids), EPA (E-series resolvins), and DHA (D-series resolvins, protectins and maresins) will be discussed herein. 


\section{INFLAMMATION AND ITS ONSET}

Before we discuss lipids and their role in homeostasis and host defence, we will recount the essence of the inflammatory response. Inflammation is a reaction of the microcirculation; it's a protective response initiated after infection or injury. While both local and systemic responses can be activated, inflammation is an essential biological process with the objective of eliminating the inciting stimulus, promoting tissue repair/wound healing and in the case of infection, establishing memory such that the host mounts a faster and more specific response upon a future encounter. The acute inflammatory response is a complex yet highly coordinated sequence of events involving a large number of molecular, cellular and physiological changes. It begins with the production of soluble mediators (complement, chemokines, cytokines, eicosanoids [including PGs], free radicals, vasoactive amines etc) by resident cells in the injured/infected tissue (i.e. tissue macrophages, dendritic cells, lymphocytes, endothelial cells, fibroblasts and mast cells) concomitant with the up-regulation of cell adhesion molecules on both leukocytes and endothelial cells that promote the exudation of proteins and influx of granulocytes from blood(1). Upon arrival these leukocytes, typically PMNs in the case of non-specific inflammation or eosinophils in response to allergens, primarily function to phagocytose and eliminate foreign microorganisms via distinct intracellular (superoxide, myeloperoxidase, proteases, lactoferrins) and/or extra cellular (neutrophil extracellular traps) killing mechanisms(2). It is likely that the magnitude of the infectious load and its eventual neutralization signal the next phase of active anti-inflammatory and pro-resolution(3).

\section{RESOLUTION OF INFLAMMATION}


It is important to distinguish between inflammatory resolution and inflammatory onset. At onset, local release/activation of soluble mediators (e.g. complement, vasoactive amines, cytokines, lipids) from histiocytes and stromal cells and up-regulation of cell adhesion molecules on the microvascular endothelium collectively facilitate extravascular leukocyte accumulation manifesting in Celsus' cardinal signs of inflammation - heat, redness, swelling and pain (Rudolph Virchoff added loss of function in the $19^{\text {th }}$ century)(4). This wellcharacterised phase of the inflammatory response is routinely targeted using drugs including NSAIDS and anti-TNF $\alpha$ that inhibit or antagonise the action of these inflammatory drivers forming the mainstay for treating chronic inflammatory disease. Resolution, however, switches inflammation off. In-as-much as onset is orchestrated by a host of sequentially released mediators, resolution is an active process that is no longer considered a passive event where the response was hitherto thought to simply fizzle out(5, 6). For instance, a critical requirement for the inflammatory response to switch off is the elimination of the injurious agents that initiated it in the first place. Failure to achieve this first step will lead to chronic inflammation as exemplified by chronic granulomatous disease, which results from a failure of the phagocytic NADPH oxidase enzyme system to produce superoxide and kill invading infections leading to a predisposition to recurrent bacterial and fungal infections and the development of inflammatory granulomas(7). Successfully dispensing with the inciting stimulus will signal a cessation of pro-inflammatory mediator synthesis and lead to their catabolism. This will halt further leukocyte recruitment and edema formation. These are probably the very earliest determinants for the resolution of acute inflammation, the outcome of which signals the next stage of cell clearance. The clearance phase of resolution, be it polymorphonuclear leukocyte (PMN)- or eosinophil-driven or adaptive (lymphocyte mediated) in nature, also has a number of mutually dependent steps. The clearance routes available to inflammatory leukocytes include systemic recirculation or local death by 
apoptosis/necrosis of influxed PMNs, eosinophils or lymphocytes followed by their phagocytosis or efferocytosis by recruited monocyte-derived macrophages. Once phagocytosis is complete, macrophages can leave the inflamed site by lymphatic drainage with evidence that a small population may die locally by apoptosis(8).

Eliminating the injurious agent leads to the next phase of pro-inflammatory mediator catabolism where levels of cytokines, chemokines, eicosanoids, cell adhesion molecules etc must revert back to that expressed during the pre-inflamed state. In terms of chemokines, the atypical chemokine receptors such as D6 possess the inability to initiate classical signalling pathways after ligand binding thereby acting as a type of scavenging system for proinflammatory signals such that in TPA-induced skin inflammation D6-deficient mice exhibit an excess concentration of chemokines resulting in a notable inflammatory pathology with similarities to human psoriasis, for review see(9). In addition, the work of Ariel and colleagues showed that CCL3 and CCL5 were increased in peritoneal exudates of Ccr5-/mice during the resolution of acute peritonitis. Transfer of apoptotic PMNs resulted in CCR5dependent scavenging of CCL3, CCL4 and CCL5. It transpires that CCR5 surface expression on apoptotic PMNs was reduced by pro-inflammatory cytokines and was increased by proresolution lipid mediators including lipoxin (Lx)A4(10), which will be discussed in detail later. Thus, endogenous systems exist to facilitate pro-inflammatory mediator clearance and whose function, when it becomes dysregulated, may lead to chronic inflammation. If all of these pathways of stimulus removal, inhibition of granulocyte trafficking, pro-inflammatory mediator catabolism, appropriate cell death/efferocytosis (phagocytosis of apoptotic cells) etc are followed then acute inflammation will resolve without causing excessive tissue damage and give little opportunity for the development of chronic, non-resolving inflammation. 
Each stage of the resolution cascade represents an opportunity to be harnessed to drive ongoing inflammatory diseases down a pro-resolution pathway. Yet, we caution that this will not be a panacea for all diseases driven by ongoing inflammation. We suspect that resolution processes may vary from tissue to tissue and be dependent of the nature of the injurious stimulus. Thus, designing pro-resolution drugs will have to be organ and disease specific. With that comes the need for more appropriate animal models of ongoing inflammation that best reflect the intended human condition. In addition more studies must be focused on examining resolution pathways in healthy and diseased humans.

\section{RESOLUTION: A DYNAMIC PROCESS WITH CHECKS AND BALANCES}

At this stage it must be emphasised that inflammation leading to resolution is not a sequence of separate events that occur in isolation, but is a dynamic contiunuum of over-lapping events where pro- and anti-inflammation blend seamlessly into pro-resolution. For instance, proinflammatory signals are activated in an immediate and early manner concomitant with antiinflammatory signals that serve to temper the magnitude of the early onset phase of acute inflammation with PMN influx being a good barometer of inflammation severity. Over the course of hours and only after tissues have sensed that the injurious agent has been neutralised, is it safe to catabolise pro-inflammatory soluble mediators and switch off proinflammatory signalling pathways. Alongside this is the synthesis of factors that terminate further PMN trafficking and prepare the injured tissue for resolution.

In other words, while it is recognized that pro-inflammatory mediators generated in the inflamed tissue drive acute inflammation, there is also the systemic and local production of endogenous mediators that counter-balance these pro-inflammatory events. These internal checks-and-balances have evolved to avert development of pathologies such as those 
highlighted above. Lipid mediators derived from polyunsaturated fatty acids (PUFA), such as arachidonic acid (AA) and the omega-3 PUFA eicosapentaenoic (EPA) and docosahexaenoic acid (DHA), are synthesised during normal cell haemostasis or, more often, after cell activation and in conditions of stress, functioning as activators of counter-regulatory, antiinflammatory and pro-resolution mechanisms. Interestingly, these immuno-modulatory effects are also found with a family of lipids, called prostanoids, which help to drive some of the cardinal signs of inflammation (heat, redness, swelling, pain and loss of function). As the role of lipids in inflammation is diverse, this review aims to provide an update of AA/DHA/EPA-derived signaling molecules that not only drive acute inflammation but also counter-regulate its severity and bring about its timely resolution.

\section{AA METABOLISM AND THE INFLAMMATORY RESPONSE}

AA is a 20-carbon fatty acid and the main eicosanoid precursor and is a constituent of all cells. Although not freely available, stimulation by various cellular agonists including receptor-mediated agonists (i.e. formyl peptide [fMLP], interleukin-8 [IL-8], and platelet activating factor $[\mathrm{PAF}])$, microorganisms, phagocytic particles, non-specific stimuli such as damage or injury (11) activates several phospholipase enzymes (predominantly PLA2), which releases AA from membrane phospholipid stores. Once in the cytosol, AA can be metabolised via three principal pathways to form an important family of oxygenated products, collectively termed eicosanoids that are released from the source cell and act at nanomolar concentrations in an autocrine/paracrine manner on target cells. Prostaglandins (PGs) and thromboxane (collectively termed prostanoids), formed by cyclooxygenase (COX); leukotrienes (LTs) and lipoxins (LXs) by lipoxygenases (LOX) (12, 13); and epoxyeicosatrienic acids (EETs) by cytochrome P450 enzymes (14) are members of the eicosanoid family. 


\section{CYCLOOXYGENASE}

$\mathrm{COX}$ is a bifunctional enzyme that acts successively as a bis-dioxygenase and peroxidase to carry out a complex free radical reaction. It begins by catalysing the bisoxygenation and cyclisation of AA to form the hydroperoxy arachidonate metabolite $\mathrm{PGG}_{2}$ (15). After which the peroxidase element of the enzyme reduces the carbon 15 position hydroperoxide to its corresponding alcohol to form $\mathrm{PGH}_{2}(16,17)$. There are two main isoforms involved in the conversion of AA, COX-1 and COX-2. While COX-1 is constitutively expressed in most cells and tissues, COX-2 is rapidly induced when cells are challenged with inflammatory stimuli (18). Although not exclusive, it is generally accepted that COX-1 is involved in cellular housekeeping functions necessary for normal physiological activity whereas COX-2 acts primarily at sites of inflammation. Formation of biologically active prostanoids from $\mathrm{PGH}_{2}$ occurs through the actions of a set of synthases that are expressed in a tissue and cell type-selective fashion. These synthases include prostaglandin D synthase (PGDS) (19) prostaglandin E synthase (PGES) (20), prostaglandin F synthase (PGFS) (21), prostaglandin I synthase (PGIS) (22), and thromboxane A synthase (TXAS) (23), which form $\mathrm{PGE}_{2}, \mathrm{PGF}_{2 \alpha}$, $\mathrm{PGI}_{2}$ (also known as prostacyclin) and $\mathrm{TXA}_{2}$ respectively. It is the differential expression of these enzymes within cells that determines the profile of prostanoid production. For example, mast cells predominantly produce $\mathrm{PGD}_{2}$ while macrophages produce $\mathrm{PGE}_{2}$ and $\mathrm{TXA}_{2}$. Moreover, alterations in the profile of prostanoid synthesis can occur upon cell activation such that resting macrophages produce $\mathrm{TXA}_{2}$ in excess of $\mathrm{PGE}_{2}$, but upon cell activation this ratio changes to favor $\mathrm{PGE}_{2}$ (24). Several biochemical mechanisms have been proposed to explain this altered synthetic profile. Firstly, it has been suggested that physical compartmentalisation of COX-1 and COX-2 with specific terminal synthases could link the 
activity of these enzymes with the synthesis of specific prostanoid end products (25). Secondly, some of the synthases are inducible and their expression may be regulated by environmental signals. For example, expression of the glutathione-dependent isoform of PGEsynthase is enhanced by IL-1 $\beta$ (26). Finally, it has been proposed that differences in substrate affinity and kinetics of PGE-synthase and TXA-synthase account for different production profiles of resting and activated monocytes (27). There is also evidence that the two COX isoforms may preferentially contribute to the synthesis of distinct prostanoids. For instance, in primary peritoneal macrophages, expressing all terminal synthases, $\mathrm{COX}-1$ yields a balance of prostanoids (i.e. $\mathrm{PGE}_{2}, \mathrm{PGD}_{2}, \mathrm{PGI}_{2}$ and $\mathrm{TXA}_{2}$ ) while COX-2 preferentially generates only $\mathrm{PGE}_{2}$ and $\mathrm{PGI}_{2}(28)$.

The biological effect of prostanoids is initiated by binding to specific cell-surface receptors. Currently there are nine known prostanoid receptors in mice and man: the PGD receptors DP1 and DP2, the $\mathrm{PGE}_{2}$ receptors, EP1, EP2, EP3 and EP4; the PGF receptor, FP; the PGI receptor, IP; and the TXA receptor, TP. In addition, there are splice variants of the EP3, FP and TP receptors differentiated only in their C-terminal tails. All belong to the G-protein coupled receptor (GPCR) superfamily of seven transmembrane spanning proteins, with the exception of DP2 (also known as CRTH2), which is a member of the chemoattractant receptor family (29-31). The IP, DP1, EP2 and EP4 receptors signal through $\mathrm{G}_{\mathrm{s}}$ resulting in an increased intracellular cAMP, whereas the EP3 receptor couples to $G_{i}$ to reduce cAMP. M EP1, FP and TP receptors signal through $\mathrm{G}_{\mathrm{q}}$ to induce calcium mobilization.

\section{PROSTANOIDS}

In the mid 1930s potent bioactive compounds in human semen were identified as prostanoids (32). Today it is appreciated that prostanoids are generated in most tissues and cells, 
modulating a wide range of biological processes such as smooth muscle tone (33-35), vascular permeability $(36,37)$, hyperalgesia (38), fever (39-41), and platelet aggregation (42). Indeed, the clinical importance of prostanoids is emphasised by the fact that prostanoid biosynthesis is the target of non-steroidal anti-inflammatory drugs (NSAIDs), one of the most widely used classes of pharmacotherapeutic agents for the treatment of chronic inflammatory diseases emphasizes the clinical importance of these lipids

The more widely studied prostanoids, $\mathrm{PGE}_{2}$ and $\mathrm{PGI}_{2}$, both enhance vasodilation(43), oedema formation and vascular permeability particularly in the presence of histamine, bradykinin and 5-HT (44-49). Genetic depletion of their respective receptors (IP, EP2 and EP3) in mice significantly reduced pleural exudation after insult with carrageenin or zymosan $(50,51)$. $\mathrm{PGE}_{2}$ is also one of the most potent pyretic agents known with elevated concentrations found in cerebrospinal fluid taken from patients with bacterial or viral infections (52). Indeed, a number of lines of evidence from EP-deficient mice have shown that the febrile response to $\mathrm{PGE}_{2}$ occurs through the action of $\mathrm{PGE}_{2}$ on the EP3 receptor present on sensory neurons in the periphery and brain (53-56). This has been postulated to cause an increase in thermogenesis through activation of brown adipose tissue and reduced passive heat loss through the skin by tail artery vasoconstriction (57-61). Although none of the COXmetabolites overtly cause pain, $\mathrm{PGI}_{2}$ and $\mathrm{PGE}_{2}$ cause peripheral and central hyperalgesia when bound to IP, EP1, EP3 and EP4 receptors, respectively, by reducing the threshold of nociceptor sensory neurons to stimulation $(34,38,62-70)$.

In addition, prostanoids play an important role in protecting against oxidative injury in cardiac tissue (71) and in maintaining cardiovascular (CV) homeostasis. Indeed, the protective effect has been highlighted/demonstrated in clinical studies undertaken with NSAIDs, which found 
that COX-2-specific inhibitors increase the risk of stroke, myocardial infarction (MI), thrombosis, systemic and pulmonary hypertension, congestive heart failure, and sudden cardiac death $(72,73)$. Furthermore, deleting specific prostanoid synthases and receptors result in an augmentation of ischemia/reperfusion injury (74) as well as exacerbating the decline in cardiac function after $\operatorname{MI}(75,76)$. The maintenance of $\mathrm{CV}$ health is dependent on a very fine balance between vasodilatory $\mathrm{PGI}_{2}$ and pro-thrombotic $\mathrm{TXA}_{2}(77,78)$, where $\mathrm{PGI}_{2}$ functions to counterbalance the actions of $\mathrm{TXA}_{2}$ (73). Indeed, $\mathrm{PGI}_{2}$ released from endothelial cells and in synergy with NO prevent $\mathrm{TXA}_{2}$-induced platelet aggregation and thrombosis (42, 79, 80). TXA $_{2}$ is derived from platelet COX-1 causing platelet aggregation and vascular smooth muscle contraction (81-83). Clinical CV diseases, such as unstable angina, MI and stroke can be a result of overproduction of $\mathrm{TXA}_{4}$. Importantly, the cardio-protective properties of aspirin can be attributed to the covalent inhibition of COX-1 (84).

As well as having 'pro-inflammatory' properties, many prostanoids also exert immunosuppressive effects through upregulation of intracellular cAMP (85-87). For example, $\mathrm{PGE}_{2}$ and $\mathrm{PGI}_{2}$ reduce the ability of inflammatory leukocytes to phagocytose and kill microorganisms (88-93), as well as inhibit the production of downstream pro-inflammatory mediators (94-100) while, in contrast, enhancing the production of IL-10 and IL-6 (101, 102). Indeed, in a number of conditions associated with increased susceptibility to infection, including cancer (103), aging (104) and cystic fibrosis $(105,106)$ overexpression of $\mathrm{PGE}_{2}$ has been reported. Interestingly, during the onset phase of inflammation, $\mathrm{PGE}_{2}$ indirectly results in pro-resolution effects by switching on the transcription of enzymes required for the generation of LXs (107), resolvins (Rvs) and protectins (PDs) (108-111), other classes of bioactive lipids that are potent pro-resolution mediators.. 
As well as eliciting immuno-modulatory and anti-inflammatory effects in the same manner as described for $\mathrm{PGE}_{2}$ and $\mathrm{PGI}_{2}$ via ligation to $\mathrm{DP} 1, \mathrm{PGD}_{2}$ can also act independently of DP1 and DP2 receptor activation when non-enzymatically dehydrated into biologically active prostaglandins of the $\mathbf{J} 2$ series (e.g. $\mathrm{PGJ}_{2}, \Delta 12,14-\mathrm{PGJ}_{2}$ and 15 -deoxy- $\Delta 12,14-\mathrm{PGJ}_{2}[15 \mathrm{~d}-$ $\left.\mathrm{PGJ}_{2}\right]$ ) (112-116). These so called cyclopentenone PGs form covalent attachments with reactive sulphydryl groups on intracellular regulatory proteins, which enables modulation of their function (117-119). For instance, $15 \mathrm{~d}_{-} \mathrm{PGJ}_{2}$ upon ligation to the nuclear receptor PPAR- $\gamma$ (120), decreases pro-inflammatory cytokine release and modifies gene expression $(121,122)$ as well as directly inhibiting the actions of $\mathrm{I} \kappa \mathrm{B}$ kinase (IKK), which is responsible for the activation of NF- $\kappa \mathrm{B}$ (123-125). 15d-PGJ 2 , independently of PPAR- $\gamma$, can preferentially inhibit monocyte rather than neutrophil trafficking through differential regulation of celladhesion molecule and chemokine expression $(8,126-128)$; regulate macrophage activation and pro-inflammatory gene expression (129); and induce leukocyte apoptosis through a caspase-dependent mechanism $(8,115,130-133)$. Moreover, it has been shown that $\mathrm{PGD}_{2}$ derived compounds function as endogenous breaking signals for lymphocytes to stimulate resolution (134).

\section{LIPOXYGENASE}

LOX enzymes, including 5-, 12-, or 15-LOX in leukocytes, platelets and endothelial cells, respectively, metabolise AA. The generation of the slow-reacting substances of anaphylaxis ( $\mathrm{LTC}_{4}, \mathrm{LTD}_{4}$ and $\mathrm{LTE}_{4}$ : potent mediators of the allergic response) (135) and $\mathrm{LTB}_{4}$, a powerful polymorphonuclear (PMN) leukocyte (i.e. neutrophils and eosinophils) chemoattractant $(136,137)$ is elicited by Leukocyte 5 -LOX. Due to its involvement in LT synthesis, 5-LOX has received the most attention in inflammation research. Therefore, the remainder of this section will concentrate specifically on this pathway. 
Once activated, 5-LOX converts AA into a hydroperoxide by inserting molecular oxygen into AA at positions 5 aided by the 5-LOX activating protein (FLAP). Termed 5hydroperoxyeicosatetraenoic acid (5-HPETEs), this intermediate is then rapidly reduced to 5hydroxyeicosatetraenoic acid (5-HETE). 5-HPETE can also be converted by removal of water to an unstable 5,6-epoxide containing a conjugated triene structure called $\mathrm{LTA}_{4}$, which is then converted to either $\mathrm{LTB}_{4}$ by insertion of a hydroxyl group at carbon-12 (C-12) through the action of $\mathrm{LTA}_{4}$ hydrolase $(138,139)$ or $\mathrm{LTC}_{4}$ by addition of the glutathionyl group at C-6 by $\gamma$-glutamyl-S-transferase (140). In most cases $\mathrm{LTB}_{4}$ and 5-HETE are subsequently secreted from the cell by an unidentified protein carrier (141). LTC $_{4}$ is also exported, but by the ATPdependent multidrug resistance proteins (142), including MRP1 and MRP2. After export, $\mathrm{LTC}_{4}$ is metabolised by the cleavage of glutamic acid by $\gamma$-glutamyl transpeptidase to form $\mathrm{LTD}_{4}$, which can be further modified by removal of a glycine by cysteinyl glycinase to produce $\mathrm{LTE}_{4}$. Unlike COX, 5-LOX is inactive in quiescent cells but becomes enzymatically functional after cell activation by increases in intracellular calcium (143) enhanced by ATP (144), or by phosphorylation, which can occur without an increase in calcium (145).

Heptahelical receptors of the rhodopsin class located on the outer leaflet of the plasma membrane of structural and inflammatory cells mediate the effects of LTs $(146,147)$. To date, four subtypes have been described, B leukotriene receptor 1 and 2 (BLT1 and BLT2), and cysteinyl leukotriene receptor 1 and 2 (cys-LT1 and cys-LT2). Once LTs have bound, a signal is sent via a G-protein in the cytoplasm to increase intracellular calcium and block formation of cAMP, which then alters various cellular activities, ranging from motility to transcriptional activation. While Cys-LT1 mediates broncho-constriction, mucus secretion, and oedema accumulation in airways (148), Cys-LT2 contributes to inflammation, vascular permeability 
and tissue fibrosis in lungs $(149,150)$. Indeed, overexpression of Cys-LT1 is seen in patients with asthma or chronic rhinosinusitis who have aspirin sensitivity (151). In contrast, BLT1 is a high-affinity receptor for $\mathrm{LTB}_{4}$, mediating all of its chemo-attractant and pro-inflammatory properties (147). Although BLT2 acts in a similar fashion to BLT1, LTB 4 affinity towards BLT1 is much higher. Interestingly, studies employing both in vitro and a murine model of inflammation demonstrate that $\mathrm{LTB}_{4}$ ligates and activates the anti-inflammatory nuclear receptor PPAR- $\alpha(152-155)$.

\section{LEUKOTRIENES IN INFLAMMATION}

LTs are generated at sites of infection/inflammation primarily by inflammatory cells, including PMNs, macrophages and mast cells and play a critical role in the inflammatory response by acting as pro-inflammatory lipid mediators. Physiologically, each of the 5-LOXderived compounds has a distinct role in driving different phases of inflammation. For example, $\mathrm{LTB}_{4}$ attracts and activates neutrophils, monocytes, and lymphocytes, a hallmark of tissue inflammation $(147,156,157)$, whereas $\mathrm{LTD}_{4}$ is a potent chemoattractant for eosinophils (158). The cysteinyl LTs ( $\mathrm{LTC}_{4}, \mathrm{LTD}_{4}$ and $\left.\mathrm{LTE}_{4}\right)$ on the other hand increase vascular permeability and plasma leakage, leading to oedema that is characteristic of inflammation (159-163). Pathologically, LTs contribute to a variety of inflammatory and allergic diseases, such as rheumatoid arthritis, inflammatory bowel disease (IBD), psoriasis, allergic rhinitis, bronchial asthma, cancer, atherosclerosis and osteoarthritis (164). This can be seen in asthmatic patients where antileukotriene therapy (i.e. 5-LOX inhibition by zileuton and CysLT1 blockage by montelukast or zafirlukast) resulted in benefitted from improved pulmonary function, symptoms, and overall quality of life (165-167). 
The role of LTs in CV disease has been the subject of intense investigation. In atherosclerotic lesions for example, 5-LOX activity/levels are associated with the severity of the lesion (168) and plaque instability (169). Furthermore, both LTB $_{4}$ and cysLTs participate in the development of atherosclerotic lesions in animals and in vitro. $\mathrm{LTB}_{4}$ increases recruitment of monocytes and their differentiation to foam cells (170), as well as intimal hyperplasia (171). CysLTs on the other hand enhance the recruitment of leukocytes into the arterial wall and contribute to thrombosis and vascular remodeling $(172,173)$. Interestingly in humans, the incidences of strokes and MI in certain populations has been linked to variants of the genes that encode FLAP and $\mathrm{LTA}_{4}$ hydrolase, which cause an overproduction of LTs (174-176). Indeed, upon treatment with a FLAP inhibitor (veliflapon), a potent biomarker of inflammation, C-reactive protein, was reduced in one population of patients with a history of MI and one of the variants mentioned above (177). Despite their pathophysiologic role, it has now become apparent that LTs are important participants in the host response against infection (178). For instance, 5-LOX-deficient mice or pharmacological inhibition of LT synthesis caused increased mortality and reduced microbial clearance after challenge with a variety of microbes (e.g. bacteria, mycobacteria, fungi, parasites(179-184). Similarly, LTdeficient alveolar macrophages also displayed impaired phagocytosis and intracellular killing of bacteria, an effect that could be overcome with the exogenous introduction of $\mathrm{LTB}_{4}$ or cysLTs $(180,185)$. Interestingly, LT deficiency is also a feature of a number of clinical conditions that are associated with impaired microbial clearance (Human immunodeficiency virus [HIV] infection, malnutrition, cigarette smoking, vitamin D deficiency and post-bone marrow transplantation) (186-191). It is believed that LTs enhance microbicidal activities in leukocytes by upregulating production of nitric oxide $(192,193)$ and the secretion of microbial peptides (194) as well as activating NADPH oxidase to generate ROI (185). Recently, it has been demonstrated that $\mathrm{LTB}_{4}$ may also possess anti-inflammatory properties 
through ligation to PPAR- $\alpha$ in its parent cell (155). It has been suggested that this activation in turn leads to its own catabolism thus facilitating resolution of the inflammatory process. This hypothesis/theory/stipulation is conceivable /further demonstrates how inflammation is such a finely balanced process that is invoked when required, yet limited and resolved when it is no longer needed.

\section{5-OXO-6,8,11,14-EICOSATETRAENOIC ACID}

5-LOX activity also results in the generation of 5-oxo-6,8,11,14-eicosatetraenoic acid (5-oxoETE), which has potent biological activities that have only recently being appreciated, including eosinophil activation and chemoattraction. It is formed by the oxidation of $5 S$ HETE by 5-hydroxyeicosanoid dehydrogenase (5-HEDH), a microsomal enzyme widely distributed in both inflammatory and structural cells including leukocytes and platelets (195). 5-HEDH however, cannot generate 5-oxo-ETE without $\mathrm{NADP}^{+}$, which is available in large quantities during the respiratory burst, neutrophil apoptosis and oxidative stress $(196,197)$. Other endogenously occurring PUFA (sebaleic acid, Mead acid and EPA) can also be converted to analogous 5-oxo-fatty acids following oxidation by 5-LOX forming products that are also granulocyte chemoattractants (198-200). Furthermore, both enzymatic and nonenzymatic pathways can further modify 5-oxo-ETE to produce several additional eicosanoids (201).

5-oxo-ETE acts via OXE receptor (OXE-R), a distinct orphan G-protein coupled receptor (GPCR) (202, 203) that is most highly expressed in human peripheral leukocytes, lungs, kidney, liver and spleen (204, 205). The relative expression of OXE-R in eosinophils, neutrophils and macrophages is 200:6:1 (205). OXE-R, once coupled to a $\mathrm{G}_{\mathrm{i} / \mathrm{o}}$-protein (197, 206, 207), activates a number of distinct intracellular signaling pathways including PLC $\beta$ 


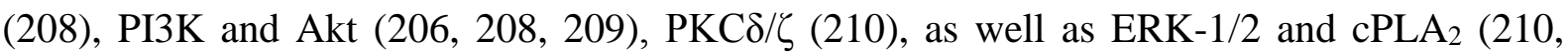
211), which, in turn, could lead to further production of AA-derived metabolites. OXE-R may also inhibit the cascade mediated by adenylyl cyclase and cAMP (204).

\section{5-OXO-ETE AND INFLAMMATION}

5-oxo-ETE is produced by eosinophils, neutrophils, basophils and monocytes and like other inflammatory lipids it acts in an autocrine manner. In addition to its most potent property as a chemoattractant for eosinophils (200), 5-oxo-ETE also induces calcium mobilisation, actin polymerisation, CD11b expression, and L-selectin shedding (201). Furthermore, 5-oxo-ETE induces degranulation and superoxide production in leukocytes primed with cytokines such as granulocyte macrophage-colony stimulating factor (GM-CSF) and TNF- $\alpha$, an effect not mirrored in naive cells $(207,211)$. In addition 5-oxo-ETE stimulates human monocytes to secrete GM-CSF (212), which is a potent survival factor for eosinophils. In prostrate tumour cells this lipid prevents apoptosis/proliferation $(213,214)$.

\section{LIPOXINS - BIOSYNTHESIS AND RECEPTORS}

Lipoxins (LXs) are a series of trihydroxytetraene-containing bioactive eicosanoids that were first isolated from human leukocytes in the mid 1980's (13). However, in contrast to LTs and 5-oxo-ETEs, which are manufactured by intracellular biosynthesis, LXs are generated through cell-cell interactions by a process known as transcellular biosynthesis. In different human cell types, during the first biosynthetic step of LX biosynthesis, LOX inserts molecular oxygen into AA. This can be achieved by two major routes - the first pathway involves the oxygenation of AA at C-15 by 15-LOX in eosinophils, monocytes, or epithelial cells (found in the respiratory tract, gastrointestinal tract and oral cavity), yielding $15 S$-HPETE. Following secretion, $15 S$-HPETE is taken up by either PMNs or monocytes and rapidly converted into 
5,6-epoxytetraene by 5-LOX, which is hydrolysed within these recipient cells by either $\mathrm{LXA}_{4}$ or $\mathrm{LXB}_{4}$ hydrolase to bioactive $\mathrm{LXA}_{4}$ or $\mathrm{LXB}_{4}$. Interestingly, this process also markedly reduces the formation of LTs, which requires 5-LOX to convert AA into LTA4 (215-217). Moreover, it has been found that the $15 S$-HETE synthesised via this pathway can also be esterified and stored within the membranes of neutrophils, specifically inositol-containing phospholipids. Upon cell stimulation, $15 S$-HETE is rapidly released and transformed to a second signal, such as $\mathrm{LXA}_{4}$, to regulate the function of the neutrophil (218). The second major route of LX biosynthesis occurs in a $\mathrm{LTA}_{4}$-dependent manner, involving peripheral blood platelet-leukocyte interactions. Leukocyte 5-LOX converts AA into LTA4, which is released, taken up by adherent platelets, and subsequently transformed to $\mathrm{LXA}_{4}$ and $\mathrm{LXB}_{4}$ via the LX synthase activity of human 12-LOX (219). A third unorthodox route of LX generation occurs after the exogenous administration of aspirin (but not other conventional NSAIDs), which irreversibly acetylates COX-2 in endothelial cells and other cell types. Rather than COX-2 converting AA into $\mathrm{PGG}_{2}$, acetylation causes the transformation of AA into $15 R$ HETE (C-15 alcohol carried in the $R$-configuration). This is then rapidly metabolised in a transcellular manner by adherent leukocyte, vascular endothelial or epithelial 5-LOX to form 15 epimeric-LX (15-epi-LXs) or aspirin-trigged LXs (ATL) that carry their C-15 alcohol in the $\mathrm{R}$ configuration rather than $15 \mathrm{~S}$ native LX. ATL's share many of the antiinflammatory/pro-resolution characteristics of the native LXs.

$\mathrm{LXA}_{4}$ and 15-epi-LXs elicit their multi-cellular responses via ALX (FPRL1 receptor), a specific G-protein-coupled receptor (GPCR) isolated and cloned in human, mouse and rat tissues (220-222). Human ALX was subsequently identified and cloned in several types of leukocytes, including monocytes (223) and T cells (224), as well as resident cells such as macrophages, synovial fibroblasts (225) and intestinal epithelial cells (226). One of the 
functions attributed to ALX is in mediating the multi-cellular responses of $\mathrm{LXA}_{4}$ and 15-epiLXs. Studies in transgenic models have shown its selectivity towards $\mathrm{LXA}_{4}$ and 15-epilipoxin $\mathrm{A}_{4}$ (not for $\mathrm{LXB}_{4}, \mathrm{LTB}_{4}, \mathrm{LTD}_{4}$ or $\left.\mathrm{PGE}_{2}\right)$ with high affinity $(\mathrm{Kd}=1.7 \mathrm{nM})$ [231]. ALX also has the ability to interact with other small peptides/proteins such as Ac2-26 and glucocorticoid-derived annexin-1, which carry out similar anti-inflammatory effects as LXs and 15-epi-LXs. Evidence that the protective effects of LXs and 15-epi-LXs were both ligand- and receptor-dependent arose from studies in transgenic mice over-expressing human ALX (227-229). In a zymosan-induced peritonitis model, infiltration of neutrophils was also substantially diminished in transgenic mice compared to their wild-type equivalents (227) with the site of lipoxin action being the leukocyte/endothelial interface mediated by the generation of nitric oxide's anti-adhesive properties (230).

ALX activation inhibits NADPH oxidase assembly, which, in turn, reduces superoxide anion generation by neutrophils through accumulation of polyisoprenoid presqualene diphosphate (PSDP) (231). Indeed, it has been demonstrated that inhibition of pro-inflammatory genes such as neutrophil chemoattractant IL-8 occurs via an ALX-dependent peroxynitrite-mediated signaling pathway (232). Moreover, peroxynitrite-induction of IL-8 in response to LPS, TNF$\alpha$ or IL- $\beta$ in human leukocytes occurs via a NFkB and AP-1 dependent pathway $(233,234)$. 15-epi-LX analogues also regulate an ALX-dependent p38/MAPK cascade, known to promote chemotaxis by inhibiting leukocyte-specific AP-1 phosphorylation and activation (235). In addition to ALX, LXs also function as partial agonists to a subclass of rhodopsin receptors (CysLT1) more commonly activated by LTs, mediating bioactions in several tissues and cell types other than leukocytes $(221,236)$. At nanomolar concentrations $\mathrm{LXA}_{4}$ has been shown to compete for binding with $\mathrm{LTD}_{4}$ on mesangial cells (236) and human umbilical vein endothelial cells (HUVECs) $(222,237)$ as well as opposing the pro-inflammatory effects of 
$\mathrm{LTD}_{4}$. There is also evidence that another intracellular receptor, the $\mathrm{Ah}$ receptor (AhR) mediates the bioactions of LXs. This receptor is a ligand activated transcription factor that controls several of the biologic actions of LXs, such as increasing the expression of suppressor of cytokine signalling 2 (SOCS-2) (238-240).

\section{LIPOXINS IN INFLAMMATION}

Lipoxins are anti-inflammatory at nanomolar concentrations controlling both granulocyte (neutrophil and eosinophil) and monocyte entry to sites of inflammation. Yet, while they inhibit the transmigration of neutrophils and eosinophils down a chemokine gradient into inflamed sites (241-244), they promote non-inflammatory infiltration of monocytes required for resolution and wound healing (245), without inducing neutrophil degranulation or release of other reactive oxygen species (232). Indeed, the ability of LXs to diminish neutrophil trafficking was corroborated when an analogue of 15-epi-LX was intravenously administered to BLT1 knockout mice that have dramatically elevated neutrophils in the lungs after high limb ischemia-reperfusion (246). Furthermore, research in our laboratory has uncovered in humans that 15-epi-LXs regulates PMN influx in forearm blisters, accounting for low-dose aspirin's anti-inflammatory properties (247). Our additional work on resolving inflammation has revealed that humans fall into two categories, those who resolved their acute inflammatory responses in an immediate manner and those that show a more delayed or prolonged healing process, with the severity and duration controlled by endogenous epilipoxins/ALX expression(248).

At sites of inflammation, macrophages are stimulated by lipoxins to ingest and clear apoptotic neutrophils (249), which appears to be coupled to changes in the actin cytoskeleton (250). Furthermore, lipoxins elevate the levels of the anti-inflammatory cytokine TGF- $\beta 1$, which, in 
turn, down-regulates a number of pro-inflammatory pathways (251-253). It is believed that these lipids mediators are generated in situ when neutrophils express 5-LOX at the onset of resolution as they begin to apoptose (107). LXs may also counteract the fibrotic response and thus improve tissue remodelling by reducing the proliferation of fibroblasts and mesanglial cells induced by a numbers of factors, including connective-tissue growth factor, plateletderived growth factor, TNF- $\alpha, \mathrm{LTD}_{4}$ and TGF- $\beta$ (254-257). 15-epi-LXs exert the same biological effects as endogenously produced LXs, but with additional benefits that increase vasorelaxation (258), and induce endothelial cell production of anti-inflammatory nitric oxide synthesis $(230,259)$. Moreover, 15-epi-lipoxin $\mathrm{A}_{4}$ has been found to inhibit TNF- $\alpha$-induced IL-1 $\beta$ in periodontitis in vivo $(260,261)$, dampen SOCS-2 signalling (262) and inhibition of TNF- $\alpha$-induced IL-8 gene expression (226). Not surprisingly, both LXs and 15-epi-LXs have been identified and proven to exert beneficial effects in various experimental models of inflammation and human diseases, such as glomerulonephritis (263, 264), ischemia/reperfusion injury (246, 254), cystic fibrosis (265), periodontitis (266), acute pleuritis (230), asthma (267), wound healing processes in the eye (268), colitis, inflammationinduced hyperalgesia in rats, various cutaneous inflammation models (269), and microbial infection in mice $(238,270,271)$.

\section{OMEGA-3 POLYUNSATURATED FATTY ACID PATHWAY}

Omega-3 polyunsaturated fatty acids ( $\omega 3$-PUFA) have long been known to be important in not only in maintaining organ function and health but also in reducing the incidence of infection and inflammation (110, 111, 272-275). A clinical trial (GISSI-Prevenzione) assessing the benefits of aspirin with and without $\omega-3$ PUFA supplementation in patients recovering from myocardial infarctions revealed a significant decrease in mortality in the group taking the supplement (276). More recent evaluations have confirmed the importance 
of $\omega-3$ PUFA in reducing CV disease, and inflammation associated with it $(277,278)$. It was initially hypothesised that fish oils demonstrate their anti-thrombotic, immuno-regulatory and anti-inflammatory bioactions by inhibiting PGs and LTs synthesis (279). However, current opinion is that it is likely that a series of novel compounds derived from EPA and DHA are responsible for eliciting these immuno-modulatory effects. First identified in the resolving exudate of a mouse dorsal air pouch or peritonitis model using lipidomic and bio-informatic analysis $(110,111,280,281)$, these naturally occurring bioactive lipid mediators are termed resolvins, Rvs (derived from 'resolution phase interaction products'), protectins (PDs) and maresins (derived from 'macrophage mediator in resolving inflammation'). All these $\omega-3$ PUFA-derived products possess a plethora of stereospecific and potent anti-inflammatory and immuno-regulatory actions that are protective in vitro and in vivo $(282,283)$.

\section{RESOLVINS AND PROTECTINS}

Rvs can be generated from either EPA or DHA and are therefore categorised as either members of the E-series (from EPA) or D-series (from DHA). Rvs of both series were first isolated in vivo from murine dorsal air pouches treated with aspirin and EPA or DHA. Transcellular formation of E-series Rvs can occur with the conversion of EPA to $18 R$ hydroxyeicosapentanoic acid (18R-HEPE) by endothelial cells expressing COX-2 treated with aspirin. As with 15R-HETE in 15-epi-LX formation, 18R-HEPE can be released from endothelial cells to neighboring leukocytes for subsequent conversion by 5-LOX to either RvE1 or RvE2, via a 5(6) epoxide-containing intermediate $(110,284)$. This interaction is blocked by selective COX-2 inhibition but not by indomethacin or paracetamol (110). RvE1 is spontaneously produced in healthy subjects, with levels increasing after treatment with either aspirin or EPA (285). D-series Rvs, aspirin-triggered RvD1 (AT-RvD1) and RvD1 are synthesised via a pathway involving sequential oxygenations, initiated by 15-LOX or aspirin- 
acetylated COX-2 in the microvascular, respectively, followed by 5-LOX in human neutrophils with an epoxide containing intermediate. For AT-RvD1s, DHA is initially converted to epimeric $17 R$-hydroxydocosahexaenoic acid (17R-HDHA). In the absence of aspirin, however, DHA is enzymatically converted to $17 S$-HDHA (108). Interestingly, generation of E-series Rvs can also be mediated by microbial and mammalian cytochrome P450 enzymes, which convert EPA into 18-HEPE. 18-HEPE can then be transformed by human neutrophils into either RvE1 or RvE2 (110). Hence, it is possible that microbes at sites of infection may contribute to the production of Rvs in a similar pathway.

DHA also serves as a precursor for the biosynthesis of protectins (PDs) enzymatically converted by 15 -LOX to a $17 S$-hydroperoxide-containing intermediate. Subsequently, this intermediate is rapidly converted by human leukocytes into a 16(17)-epoxide that is enzymatically converted in these cells to a 10,17-dihydroxy-containing compound $(108,286)$. PDs are distinguished by the presence of a conjugated triene double bond and by their potent bioactivity. One specific DHA-derived lipid mediator, 10,17S-docosatriene was termed protectin D1 (PD1). When generated in neural tissue however, this compound is called neuroprotectin D1 (NPD1). Moreover, PD1 exhibits tissue-specific bioactivity as in humans this lipid is synthesised by peripheral blood mononuclear cells and Th2 CD4+ T-cells, while in mice it has been isolated from exudates and brain cells, human microglial cells (111) and in peripheral blood (108).

\section{RESOLVINS AND PROTECTINS IN INFLAMMATION}

One of the broader immunomodulatory properties of RvE1 is its ability to inhibit neutrophil and dendritic cell accumulation at sites of inflammation by blocking trans-endothelial migration as well as enhancing their clearance from mucosal epithelial cells $(110,285,287)$. 
Other bioactions of RvE1 includes inhibition of neutrophil ROI in response to TNF- $\alpha$ and bacterial peptide, fMLP (288), abrogation of $\mathrm{LTB}_{4}-\mathrm{BLT} 1$ signalling via NF- $\kappa \mathrm{B}$ and thus the production of pro-inflammatory cytokines and chemokines $(251,289,290)$, stimulation of macrophages to ingest apoptotic neutrophils (291), enhancement of the percentage of phagocytes present in the lymph nodes (292) and upregulation of the CC-chemokine receptor 5 (CCR5) on late apoptotic neutrophils (10), which terminates chemokine signalling, and inhibition of dendritic cells migration. More recently, RvE1 has been demonstrated to regulate the leukocyte pro-inflammatory cell surface markers, such as L-selectin, whilst selectively disrupting TX-mediated platelet aggregation (293), adding further mechanistic insight into its anti-inflammatory/pro-resolution properties. In disease states, RvE1 suppresses Porphyromonas gingivalis-induced oral inflammation and alveolar bone loss during periodontitis (294), demonstrates protective actions in trinitrobenzene-sulphonic acid-induced colitis in mice (272), as well as causing re-epithelisation of mouse cornea after thermal-injury (268). Overall, RvE1 initiates resolution of inflammation and causes decreased numbers of PMNs at sites of inflammation early during the response, reviewed in (283).

Structure-activity assays have elucidated that RvE1 binds to an orphan G-protein coupled receptor belonging to the same cluster as $\operatorname{ALX}\left(\right.$ ChemR23), with a high affinity $\left(\mathrm{K}_{\mathrm{d}}=\right.$ 48.3nm). This coupling down-regulates the activity of NF- $\kappa B$ and hence TNF- $\alpha$ synthesis, as well as initiating signalling pathways involved in initiating mitogen-activated protein kinase (MAPK) (285). Indeed, ChemR23 activation has been demonstrated to inhibit one of the most prominent RvE1 actions, dendritic cell migration (285). Although it has been found in myeloid, gastro-intestinal, kidney, brain, and CV tissue, the percentage of ChemR23 expression is highly variable. For example, it has been demonstrated that ChemR23 is markedly increased on the surface of human monocytes but less so on neutrophils by anti- 
inflammatory mediators such as TGF- $\beta$ (295). Like ALX, ChemR23 acts as a receptor towards peptide ligands, including chemerin that also act as anti-inflammatory mediators (296). RvE1 also appears to interact with the $\mathrm{LTB}_{4}$ receptor, BLT1 and act as a partial antagonist preventing neutrophil activation (289). Therefore, it can be concluded that RvE1 couples to two distinct receptors to both suppress pro-inflammatory mechanisms and enhance resolution pathways.

RvE2 is a second member of the EPA-derived family of E-series resolvins but is structurally distinct from RvE1. In human PMNs, it is generated at higher concentrations than RvE1, but is equipotent when given intravenously and additive when administered alongside RvE1 (292). As with RvE1, RvE2 suppresses PMN migration into the peritoneum after zymosan (292). Although it is still unclear what receptor RvE2 couples to, its identification is the subject of ongoing research.

D-series Rvs are derived from DHA comprise four bioactive compounds, RvD1, RvD2, RvD3 and RvD4 (108). Like RvE1, RvD1/D2 exerts both anti-inflammatory and pro-resolution properties by blocking neutrophil infiltration, while in contrast enhancing macrophage phagocytosis of apoptotic PMNs (297-299). The latter occurs via the binding of RvD1 to either ALX or an orphan receptor, GPR32 present on the surface of both PMNs and monocytes, the expression of which is upregulated by inflammatory agonists, such as zymosan and granulocyte-macrophage-colony-stimulating factor (GM-CSF) (297). Interestingly, a member of the D-series Rvs has also been shown to contain microbicidal properties in septic mice initiated by cecal ligation and puncture (CLP). RvD2, whose receptor is GPR18(300), in addition to blocking peritoneal PMN accumulation markedly 
reduced bacterial load and pro-inflammatory cytokines, which subsequently led to increased survival and improved health (298).

As mentioned above, besides D-series Rvs, DHA also acts as a precursor for the biosynthesis of PDs. One member, PD1 has been demonstrated to be synthesised in human brain, microglial (111), peripheral blood mononuclear cells and Th2 CD4+ T-cells (108, 286). Similarly to Rvs, PD1 exerts potent immuno-regulatory effects that include inhibiting neutrophil migration and toll-like receptor-mediated activation (301), suppression of Th2 inflammatory cytokines and pro-inflammatory lipid mediators (302), as well as the upregulation of CCR5 on PMNs (10). PD1 also blocks T-cell migration in vivo and promotes T-cell apoptosis (303). In disease states, PD1 has been proven to be protective in experimental models of ischemic stroke (109), oxidative stress (304-306), asthma (302), ischemiareperfusion renal injury (301) and Alzheimer's (307). Indeed, Alzheimer's patients given DHA-rich dietary supplements have reduced production of IL-1 $\beta$, IL-6 and granulocytecolony-stimulating factor (G-CSF) in peripheral blood mononuclear cells (308). As with RvE2, a receptor is yet to be identified. It is likely however that it couples to a distinct receptor to RvE1 as its anti-inflammatory effects are additive with those of RvE1 in vivo.

\section{MARESINS}

Maresins (MaR) were identified in 2008 after $17 S$-D series Rvs, PDs as well as $14 S$ hydroxydocosahexaenoic acid (14S-HDHA) were isolated from the resolution phase of mouse peritonitis were added to stimulated resident peritoneal macrophages (281). Macrophages then convert these intermediates to novel dihydroxy-containing products, which possesses potent anti-inflammatory and pro-resolving properties. Although the exact biosynthetic pathway is yet to be elucidated a hypothetical scheme was proposed. It is thought that DHA is 
converted to $14 S$-hydroperoxydocosahexaenoic acid (14S-HPDHA; maresin, MaR1) via 12or 15 -LOX, followed by either reduction to $14 S$-HDHA and/or via double dioxygenation (e.g. sequential 12-LOX-5-LOX) to generate a metabolome of MaR1, $7 S, 14 S$ dihydroxydocasahexaenoic acid ( $7 S, 14 S$-diHDHA). Though maresins have only been recently it has been reported that, as with Rvs and PD1, MaR1 block the infiltration of PMNs, whilst stimulating macrophage phagocytosis of apoptotic PMNs/zymosan (281). Its metabolome $7 S, 14 S$-diHDHA was active but less potent.

\section{CYTOCHROME P450}

In the last decade, interest into a third less well-characterised pathway of AA metabolism, cytochrome P450 (CYP) has been rekindled. CYP are families of membrane-bound, haemecontaining enzymes found in the liver, brain, kidneys, lung, heart and the CV system, thought initially to be involved in catalysing NADPH-dependent oxidation of drugs, chemical and carcinogens $(309,310)$. It is now well-appreciated that CYPs also catalyse the conversion of fatty acids including AA into products which have been denoted epoxyeicosatrienoic acids (EETs), hydroxyeicosatetraenoic acids (HETEs) and dihydroxyeicosatrienoic acids (DHETs) (311). For instance, AA is metabolised in the vascular endothelium by CYP epoxygenase to EETs (312), which can then be converted by epoxide hydrolase to the respective regioisomer of DHETs (311). In the vascular smooth muscle, AA is catalysed by CYP hydroxylases to 20HETE (313). Indeed, one particular member, CYP4F3 is highly expressed in PMNs catalysing the $\omega$-hydroxylation of LTs (314). However, it is unknown whether CYP4F3 is the source of 20-HETE produced by PMNs (315). These metabolites play a large and complex role in maintaining renal, cardiac, and pulmonary homeostasis by regulating aspects such as vascular tone and reactivity, renal and pulmonary functions, ion transport, and growth 
responses (316-318). Interestingly, they have also been demonstrated to exert potent antiinflammatory actions (319-321), detailed below.

\section{CYTOCHROME P450-DERIVED PRODUCTS AND INFLAMMATION}

EETs catalysed by CYPs 2C8, 2C9 and 2J2 prevent the adhesion of PMNs to the vascular wall by suppressing the expression of cell adhesion molecules, including intracellular adhesion molecule-1 (ICAM-1), vascular cell adhesion molecule-1 (VCAM-1) and E-selectin on the surface of endothelial cells in response to cytokines (TNF- $\alpha$ and IL- $1 \alpha$ ), and LPS (316, 321). Mechanistically, this is associated with inhibiting the activation of the transcription factor $\mathrm{NF}-\kappa \mathrm{B}$ via the inhibitor of $\kappa \mathrm{B}$ kinase (IKK) (321). As a consequence, EETs may therefore have the propensity to down-regulate various cytokine-induced pro-inflammatory signalling pathways downstream of NF- $\mathrm{KB}$ activation. Indeed, it was recently reported that EETs display hyperalgesic bioactions during experimental inflammatory pain $(319,320)$. It was also shown that EETs could directly activate peroxisome-proliferator-activator receptorgamma (PPAR- $\gamma$ ) in endothelial cells (322) with EETs-mediated anti-inflammatory effects demonstrated to be blocked by PPAR- $\gamma$ antagonists (322). EETs released from platelets have been shown to exert anti-thrombotic properties by inhibiting platelet aggregation induced by AA and vascular injury (323-325). It was also demonstrated that EETs could act in a profibrinolytic manner by increasing the expression of tissue plasminogen activator in a cAMPdependent mechanism, thus suggesting that they could play an important role in controlling the fibrinolytic balance in the vessel wall (326). It was suggested that the anti-inflammatory properties of EETs occurred through its ligation to a cell surface receptor. It was reported that EETs bind with high-affinity to an 'EET-receptor' on the surface of a monocytic cell line, belonging to a specific class of GPCRs (327). The identity of this receptor and its role, if any, in initiating the immuno-modulatory actions of EETs is yet to be determined. 
CYP hydroxylases metabolites also exhibit anti-inflammatory properties. Similarly to EETs, 16-HETE can also block the adhesion of leukocytes to the endothelium (315). In fact, it also suppresses the synthesis of LTs as well as inhibiting rises in cerebrospinal fluid pressure (index of tissue damage and swelling) in thrombo-embolic model of stroke in rabbits (315). Furthermore, 20-HETE and 16-HETE released from PMNs in response to factors that activate phospholipase (platelet activating factor, calcium and thrombin) also inhibit TX-induced platelet aggregation (328). Therefore, it can surmised that not only do metabolites of CYPs maintain renal and CV health, but they also regulate other multiple signalling pathways including inflammation, fibrinolysis, platelet aggregation, and cellular injury.

\section{SUMMARY}

Studies on inflammation and its resolution have advanced our understanding of leokocuye trafficking, efferocytosis and pro-inflammatory leukocyte clearance as well as immunesuppressive eicosanoids, specialised immune-regulatory cells and cytokine catabolism. These pathways converge on the termination of acute inflammatory responses and contribute to the notion that chronic inflammation is avoided and wounds healed in an appropriate manner(329, 330). Implicit therein is that tolerance is not compromised making the host susceptible to autoimmunity. AA metabolites were once considered pro-inflammatory due to the effective usage of NSAIDs in the treatment of chronic inflammatory diseases. While NSAIDs have been a valuable treatment in terms of anti-inflammation and pain relief, they have recently unmasked beneficial properties of some LOX and COX products. Thus, our understanding of eicosanoids in physiology and pathology has come a long way since the earliest observations of Kurzrok and Lieb(331). Hence, PGs may drive oedema but prevent leukocyte trafficking, while at the same time elevating cAMP and impairing bacterial 
phagocytosis and killing. However, $\mathrm{LTB}_{4} / \mathrm{D}_{4}$ oppose/prevents the immune suppressive actions of $\mathrm{PGE}_{2}$, with 5-LOX metabolites thus enhancing macrophage antimicrobial functions/roles, including the phagocytosis of IgG-opsonized targets via the Fc $\lambda$ R. COX/LOX derived lipoxins, resolvins and protectins attenuate innate immune responses, aid/ameliorate/promote resolution and are proving beneficial in experimental sepsis. Thus, the role of eicosanoids in inflammation is most likely dependant on the phase of the response during which they are synthesised, tissues affected and the nature of the inciting stimulus with some AA metabolites counteracting the bio-action of others but also triggering the synthesis of other families of eicosanoids that terminate inflammation. And while eicosanoids act diversely in acute inflammation, their role in chronic, non-resolving inflammation may be far more complex. That notwithstanding it now appears that not all eicosanoids are bad as some attenuate innate immune-mediated functions and accelerate/facilitate their timely resolution. This offers a more accurate strategy in treating diseases driven by over-exuberant inflammation. 


\section{REFERENCES}

1. Serhan C, Ward P, Gilroy D. Fundamentals of Inflammation: Cambridge University Press; 2010.

2. Segal AW. How neutrophils kill microbes. Annual review of immunology. 2005;23:197-223. doi: 10.1146/annurev.immunol.23.021704.115653. PubMed PMID: 15771570; PubMed Central PMCID: PMC2092448.

3. Serhan CN, Savill J. Resolution of inflammation: the beginning programs the end. Nat Immunol. 2005;6(12):1191-7. PubMed PMID: 16369558.

4. Majno G, Joris I. Cells, Tissues and Disease. Principles of General Pathology. Second ed. New York: Oxford University Press; 2004.

5. Buckley CD, Gilroy DW, Serhan CN. Proresolving lipid mediators and mechanisms in the resolution of acute inflammation. Immunity. 2014;40(3):315-27. Epub 2014/03/25. doi: 10.1016/j.immuni.2014.02.009. PubMed PMID: 24656045; PubMed Central PMCID: PMC4004957.

6. Buckley CD, Gilroy DW, Serhan CN, Stockinger B, Tak PP. The resolution of inflammation. Nature reviews Immunology. 2013;13(1):59-66. Epub 2012/12/01. doi: 10.1038/nri3362. PubMed PMID: 23197111.

7. Segal AW, Geisow M, Garcia R, Harper A, Miller R. The respiratory burst of phagocytic cells is associated with a rise in vacuolar pH. Nature. 1981;290(5805):406-9. PubMed PMID: 7219526.

8. Gilroy DW, Colville-Nash PR, McMaster S, Sawatzky DA, Willoughby DA, Lawrence T. Inducible cyclooxygenase-derived 15-deoxy(Delta)12-14PGJ2 brings about acute inflammatory resolution in rat pleurisy by inducing neutrophil and macrophage apoptosis. Faseb J. 2003;17(15):2269-71. PubMed PMID: 14563690. 
9. Nibbs RJ, Graham GJ. Immune regulation by atypical chemokine receptors. Nat Rev Immunol. 2013;13(11):815-29. Epub 2013/12/10. PubMed PMID: 24319779.

10. Ariel A, Fredman G, Sun YP, Kantarci A, Van Dyke TE, Luster AD, et al. Apoptotic neutrophils and $\mathrm{T}$ cells sequester chemokines during immune response resolution through modulation of CCR5 expression. Nat Immunol. 2006;7(11):1209-16. Epub 2006/10/03. doi: 10.1038/ni1392. PubMed PMID: 17013391; PubMed Central PMCID: PMC1797066.

11. Piper P, Vane J. The release of prostaglandins from lung and other tissues. Ann N Y Acad Sci. 1971;180:363-85. Epub 1971/04/30. PubMed PMID: 4106477.

12. Samuelsson B, Dahlen SE, Lindgren JA, Rouzer CA, Serhan CN. Leukotrienes and lipoxins: structures, biosynthesis, and biological effects. Science. 1987;237(4819):1171-6. PubMed PMID: 2820055.

13. Serhan CN, Hamberg M, Samuelsson B. Trihydroxytetraenes: a novel series of compounds formed from arachidonic acid in human leukocytes. Biochem Biophys Res Commun. 1984;118(3):943-9. Epub 1984/02/14. doi: 0006-291X(84)91486-4 [pii]. PubMed PMID: 6422933.

14. Capdevila JH, Falck JR, Dishman E, Karara A. Cytochrome P-450 arachidonate oxygenase. Methods Enzymol. 1990;187:385-94. Epub 1990/01/01. PubMed PMID: 2233355.

15. Pagels WR, Sachs RJ, Marnett LJ, Dewitt DL, Day JS, Smith WL. Immunochemical evidence for the involvement of prostaglandin $\mathrm{H}$ synthase in hydroperoxide-dependent oxidations by ram seminal vesicle microsomes. J Biol Chem. 1983;258(10):6517-23. Epub 1983/05/25. PubMed PMID: 6406484.

16. Hamberg M, Samuelsson B. Detection and isolation of an endoperoxide intermediate in prostaglandin biosynthesis. Proc Natl Acad Sci U S A. 1973;70(3):899-903. Epub 1973/03/01. PubMed PMID: 4514999. 
17. Nugteren DH, Hazelhof E. Isolation and properties of intermediates in prostaglandin biosynthesis. Biochim Biophys Acta. 1973;326(3):448-61. Epub 1973/12/20. doi: 00052760(73)90145-8 [pii]. PubMed PMID: 4776443.

18. Dubois RN, Abramson SB, Crofford L, Gupta RA, Simon LS, Van De Putte LB, et al. Cyclooxygenase in biology and disease. FASEB J. 1998;12(12):1063-73. Epub 1998/09/16. PubMed PMID: 9737710.

19. Shimizu T, Yamamoto S, Hayaishi O. Purification of PGH-PGD isomerase from rat brain. Methods Enzymol. 1982;86:73-7. Epub 1982/01/01. PubMed PMID: 7132774.

20. Tanaka Y, Ward SL, Smith WL. Immunochemical and kinetic evidence for two different prostaglandin $\mathrm{H}$-prostaglandin $\mathrm{E}$ isomerases in sheep vesicular gland microsomes. $\mathbf{J}$ Biol Chem. 1987;262(3):1374-81. Epub 1987/01/25. PubMed PMID: 3100531.

21. Hayashi H, Fujii Y, Watanabe K, Urade Y, Hayaishi O. Enzymatic conversion of prostaglandin $\mathrm{H} 2$ to prostaglandin $\mathrm{F} 2$ alpha by aldehyde reductase from human liver: comparison to the prostaglandin $\mathrm{F}$ synthetase from bovine lung. $\mathrm{J}$ Biol Chem. 1989;264(2):1036-40. Epub 1989/01/15. PubMed PMID: 2910843.

22. DeWitt DL, Smith WL. Purification of prostacyclin synthase from bovine aorta by immunoaffinity chromatography. Evidence that the enzyme is a hemoprotein. J Biol Chem. 1983;258(5):3285-93. Epub 1983/03/10. PubMed PMID: 6338016.

23. Ullrich V, Haurand M. Thromboxane synthase as a cytochrome P450 enzyme. Adv Prostaglandin Thromboxane Leukot Res. 1983;11:105-10. Epub 1983/01/01. PubMed PMID: 6221511.

24. Bezugla Y, Kolada A, Kamionka S, Bernard B, Scheibe R, Dieter P. COX-1 and COX-2 contribute differentially to the LPS-induced release of PGE2 and TxA2 in liver macrophages. Prostaglandins Other Lipid Mediat. 2006;79(1-2):93-100. Epub 2006/03/07. doi: S1098-8823(05)00140-1 [pii] 
10.1016/j.prostaglandins.2005.11.001. PubMed PMID: 16516813.

25. Naraba H, Murakami M, Matsumoto H, Shimbara S, Ueno A, Kudo I, et al. Segregated coupling of phospholipases A2, cyclooxygenases, and terminal prostanoid synthases in different phases of prostanoid biosynthesis in rat peritoneal macrophages. J Immunol. 1998;160(6):2974-82. Epub 1998/03/24. PubMed PMID: 9510202.

26. Jakobsson PJ, Thoren S, Morgenstern R, Samuelsson B. Identification of human prostaglandin E synthase: a microsomal, glutathione-dependent, inducible enzyme, constituting a potential novel drug target. Proc Natl Acad Sci U S A. 1999;96(13):7220-5. PubMed PMID: 10377395.

27. Penglis PS, Cleland LG, Demasi M, Caughey GE, James MJ. Differential regulation of prostaglandin E2 and thromboxane A2 production in human monocytes: implications for the use of cyclooxygenase inhibitors. J Immunol. 2000;165(3):1605-11. Epub 2000/07/21. doi: ji_v165n3p1605 [pii]. PubMed PMID: 10903770.

28. Brock TG, McNish RW, Peters-Golden M. Arachidonic acid is preferentially metabolized by cyclooxygenase- 2 to prostacyclin and prostaglandin E2. J Biol Chem. 1999;274(17):11660-6. Epub 1999/04/17. PubMed PMID: 10206978.

29. Hirai H, Tanaka K, Yoshie O, Ogawa K, Kenmotsu K, Takamori Y, et al. Prostaglandin D2 selectively induces chemotaxis in T helper type 2 cells, eosinophils, and basophils via seven-transmembrane receptor CRTH2. J Exp Med. 2001;193(2):255-61. PubMed PMID: 11208866.

30. Monneret G, Gravel S, Diamond M, Rokach J, Powell WS. Prostaglandin D2 is a potent chemoattractant for human eosinophils that acts via a novel DP receptor. Blood. 2001;98(6):1942-8. Epub 2001/09/06. PubMed PMID: 11535533.

31. Xue L, Gyles SL, Wettey FR, Gazi L, Townsend E, Hunter MG, et al. Prostaglandin D2 causes preferential induction of proinflammatory Th2 cytokine production through an 
action on chemoattractant receptor-like molecule expressed on Th2 cells. J Immunol. 2005;175(10):6531-6. Epub 2005/11/08. doi: 175/10/6531 [pii]. PubMed PMID: 16272307.

32. von Euler US. On the specific vaso-dilating and plain muscle stimulating substances from accesory genital glands in man and certain animals (prostaglandins and vesiglandins). $\mathbf{J}$ Physiol. 1936;88:213-34.

33. Eckenfels A, Vane JR. Prostaglandins, oxygen tension and smooth muscle tone. $\mathrm{Br} \mathbf{J}$ Pharmacol. 1972;45(3):451-62. Epub 1972/07/01. PubMed PMID: 5072227.

34. Ferreira SH, Herman A, Vane JR. Proceedings: Prostaglandin generation maintains the smooth muscle tone of the rabbit isolated jejunum. Br J Pharmacol. 1972;44(2):328P-9P. Epub 1972/02/01. PubMed PMID: 4203346; PubMed Central PMCID: PMC1666081.

35. Main IH. The Inhibitory Actions of Prostaglandins on Respiratory Smooth Muscle. Br J Pharmacol Chemother. 1964;22:511-9. Epub 1964/06/01. PubMed PMID: 14211681.

36. Williams TJ. Prostaglandin E2, prostaglandin I2 and the vascular changes of inflammation. Br J Pharmacol. 1979;65(3):517-24. Epub 1979/03/01. PubMed PMID: 371730.

37. Williams TJ, Jose PJ. Mediation of increased vascular permeability after complement activation. Histamine-independent action of rabbit C5a. J Exp Med. 1981;153(1):136-53. PubMed PMID: 6161204.

38. Ferreira SH, Nakamura, M., de Abreu Castro, M.S. The hyperalgesic effects of prostacyclin and prostaglandin E2 Prostaglandins. 1978;16(1):31-7.

39. Feldberg W, Gupta KP. Pyrogen fever and prostaglandin-like activity in cerebrospinal fluid. J Physiol. 1973;228(1):41-53. Epub 1973/01/01. PubMed PMID: 4568386.

40. Feldberg W, Saxena PN. Fever produced by prostaglandin E1. J Physiol. 1971;217(3):547-56. Epub 1971/09/01. PubMed PMID: 5098081. 
41. Milton AS, Wendlandt S. Effects on body temperature of prostaglandins of the A, E and F series on injection into the third ventricle of unanaesthetized cats and rabbits. J Physiol. 1971;218(2):325-36. Epub 1971/10/01. PubMed PMID: 4330929.

42. Moncada S, Gryglewski R, Bunting S, Vane JR. An enzyme isolated from arteries transforms prostaglandin endoperoxides to an unstable substance that inhibits platelet aggregation. Nature. 1976;263(5579):663-5. PubMed PMID: 802670.

43. Kaley G, Hintze TH, Panzenbeck M, Messina EJ. Role of prostaglandins in microcirculatory function. Adv Prostaglandin Thromboxane Leukot Res. 1985;13:27-35. Epub 1985/01/01. PubMed PMID: 3159211.

44. Hata AN, Breyer RM. Pharmacology and signaling of prostaglandin receptors: multiple roles in inflammation and immune modulation. Pharmacol Ther. 2004;103(2):14766. PubMed PMID: 15369681.

45. Higgs EA, Moncada S, Vane JR. Inflammatory effects of prostacyclin (PGI2) and 6oxo-PGF1alpha in the rat paw. Prostaglandins. 1978;16(2):153-62. Epub 1978/08/01. PubMed PMID: 360302.

46. Komoriya K, Ohmori H, Azuma A, Kurozumi S, Hashimoto Y, Nicolaou KC, et al. Prostaglandin I2 as a potentiator of acute inflammation in rats. Prostaglandins. 1978;15(4):557-64. Epub 1978/04/01. PubMed PMID: 353901.

47. Lewis AJ, Nelson DJ, Sugrue MF. On the ability of prostaglandin E1, and arachidonic acid to modulate experimentally induced oedema in the rat paw. $\mathrm{Br} \mathrm{J}$ Pharmacol. 1975;55(1):51-6. Epub 1975/09/01. PubMed PMID: 1182349.

48. Moncada S, Ferreira SH, Vane JR. Prostaglandins, aspirin-like drugs and the oedema of inflammation. Nature. 1973;246(5430):217-9. PubMed PMID: 4586794. 
49. Williams TJ, Morley J. Prostaglandins as potentiators of increased vascular permeability in inflammation. Nature. 1973;246(5430):215-7. Epub 1973/11/23. PubMed PMID: 4271544.

50. Yuhki K, Ueno A, Naraba H, Kojima F, Ushikubi F, Narumiya S, et al. Prostaglandin receptors EP2, EP3, and IP mediate exudate formation in carrageenin-induced mouse pleurisy. J Pharmacol Exp Ther. 2004;311(3):1218-24. Epub 2004/08/19. doi: 10.1124/jpet.104.071548

jpet.104.071548 [pii]. PubMed PMID: 15316088.

51. Yuhki K, Ushikubi F, Naraba H, Ueno A, Kato H, Kojima F, et al. Prostaglandin I2 plays a key role in zymosan-induced mouse pleurisy. $\mathrm{J}$ Pharmacol Exp Ther. 2008;325(2):601-9. Epub 2008/02/08. doi: jpet.107.134494 [pii]

10.1124/jpet.107.134494. PubMed PMID: 18256172.

52. Saxena PN, Beg MM, Singhal KC, Ahmad M. Prostaglandin-like activity in the cerebrospinal fluid of febrile patients. Indian J Med Res. 1979;70:495-8. Epub 1979/09/01. PubMed PMID: 535962.

53. Dantzer R, Konsman JP, Bluthe RM, Kelley KW. Neural and humoral pathways of communication from the immune system to the brain: parallel or convergent? Auton Neurosci. 2000;85(1-3):60-5. Epub 2001/02/24. PubMed PMID: 11189027.

54. Ek M, Kurosawa M, Lundeberg T, Ericsson A. Activation of vagal afferents after intravenous injection of interleukin-1beta: role of endogenous prostaglandins. $\mathrm{J}$ Neurosci. 1998;18(22):9471-9. Epub 1998/11/05. PubMed PMID: 9801384.

55. Lazarus M, Yoshida K, Coppari R, Bass CE, Mochizuki T, Lowell BB, et al. EP3 prostaglandin receptors in the median preoptic nucleus are critical for fever responses. Nat Neurosci. 2007;10(9):1131-3. Epub 2007/08/07. doi: nn1949 [pii] 
10.1038/nn1949. PubMed PMID: 17676060.

56. Ushikubi F, Segi E, Sugimoto Y, Murata T, Matsuoka T, Kobayashi T, et al. Impaired febrile response in mice lacking the prostaglandin E receptor subtype EP3. Nature. 1998;395(6699):281-4. Epub 1998/09/29. doi: 10.1038/26233. PubMed PMID: 9751056.

57. Madden CJ, Morrison SF. Excitatory amino acid receptor activation in the raphe pallidus area mediates prostaglandin-evoked thermogenesis. Neuroscience. 2003;122(1):5-15. Epub 2003/11/05. doi: S030645220300527X [pii]. PubMed PMID: 14596844.

58. Madden CJ, Morrison SF. Excitatory amino acid receptors in the dorsomedial hypothalamus mediate prostaglandin-evoked thermogenesis in brown adipose tissue. Am J Physiol Regul Integr Comp Physiol. 2004;286(2):R320-5. Epub 2003/10/18. doi: 10.1152/ajpregu.00515.2003

00515.2003 [pii]. PubMed PMID: 14563660.

59. Morrison SF. Differential regulation of sympathetic outflows to vasoconstrictor and thermoregulatory effectors. Ann N Y Acad Sci. 2001;940:286-98. Epub 2001/07/19. PubMed PMID: 11458686.

60. Morrison SF. Raphe pallidus neurons mediate prostaglandin E2-evoked increases in brown adipose tissue thermogenesis. Neuroscience. 2003;121(1):17-24. Epub 2003/08/30. doi: S0306452203003634 [pii]. PubMed PMID: 12946696.

61. Morrison SF. Central pathways controlling brown adipose tissue thermogenesis. News Physiol Sci. 2004;19:67-74. Epub 2004/03/16. PubMed PMID: 15016906.

62. Ahmadi S, Lippross S, Neuhuber WL, Zeilhofer HU. PGE(2) selectively blocks inhibitory glycinergic neurotransmission onto rat superficial dorsal horn neurons. Nat Neurosci. 2002;5(1):34-40. Epub 2001/12/12. doi: 10.1038/nn778

nn778 [pii]. PubMed PMID: 11740501. 
63. Juhlin L, Michaelsson G. Cutaneous vascular reactions to prostaglandins in healthy subjects and in patients with urticaria and atopic dermatitis. Acta Derm Venereol. 1969;49(3):251-61. Epub 1969/01/01. PubMed PMID: 4185582.

64. Lin CR, Amaya F, Barrett L, Wang H, Takada J, Samad TA, et al. Prostaglandin E2 receptor EP4 contributes to inflammatory pain hypersensitivity. J Pharmacol Exp Ther. 2006;319(3):1096-103. Epub 2006/09/13. doi: jpet.106.105569 [pii]

10.1124/jpet.106.105569. PubMed PMID: 16966471.

65. McAdam BF, Mardini IA, Habib A, Burke A, Lawson JA, Kapoor S, et al. Effect of regulated expression of human cyclooxygenase isoforms on eicosanoid and isoeicosanoid production in inflammation. J Clin Invest. 2000;105(10):1473-82. Epub 2000/05/17. doi: 10.1172/JCI9523. PubMed PMID: 10811855.

66. Moriyama T, Higashi T, Togashi K, Iida T, Segi E, Sugimoto Y, et al. Sensitization of TRPV1 by EP1 and IP reveals peripheral nociceptive mechanism of prostaglandins. Mol Pain. 2005;1:3. Epub 2005/04/09. doi: 1744-8069-1-3 [pii]

\subsection{6/1744-8069-1-3. PubMed PMID: 15813989.}

67. Murata T, Ushikubi F, Matsuoka T, Hirata M, Yamasaki A, Sugimoto Y, et al. Altered pain perception and inflammatory response in mice lacking prostacyclin receptor. Nature. 1997;388(6643):678-82. PubMed PMID: 9262402.

68. Reinold H, Ahmadi S, Depner UB, Layh B, Heindl C, Hamza M, et al. Spinal inflammatory hyperalgesia is mediated by prostaglandin E receptors of the EP2 subtype. $\mathrm{J}$ Clin Invest. 2005;115(3):673-9. Epub 2005/02/19. doi: 10.1172/JCI23618. PubMed PMID: 15719070.

69. Solomon LM, Juhlin L, Kirschenbaum MB. Prostaglandin on cutaneous vasculature. J Invest Dermatol. 1968;51(4):280-2. Epub 1968/10/01. PubMed PMID: 5676860. 
70. Ueno A, Matsumoto H, Naraba H, Ikeda Y, Ushikubi F, Matsuoka T, et al. Major roles of prostanoid receptors IP and $\mathrm{EP}(3)$ in endotoxin-induced enhancement of pain perception. Biochem Pharmacol. 2001;62(2):157-60. Epub 2001/06/08. doi: S00062952(01)00654-2 [pii]. PubMed PMID: 11389873.

71. Smyth EM, Grosser T, Wang M, Yu Y, FitzGerald GA. Prostanoids in health and disease. J Lipid Res. 2009;50 Suppl:S423-8. Epub 2008/12/20. doi: R800094-JLR200 [pii]

10.1194/jlr.R800094-JLR200. PubMed PMID: 19095631.

72. Garcia Rodriguez LA, Tacconelli S, Patrignani P. Role of dose potency in the prediction of risk of myocardial infarction associated with nonsteroidal anti-inflammatory drugs in the general population. J Am Coll Cardiol. 2008;52(20):1628-36. Epub 2008/11/11. doi: S0735-1097(08)03064-7 [pii]

10.1016/j.jacc.2008.08.041. PubMed PMID: 18992652.

73. Grosser T, Fries S, FitzGerald GA. Biological basis for the cardiovascular consequences of COX-2 inhibition: therapeutic challenges and opportunities. J Clin Invest. 2006;116(1):4-15. Epub 2006/01/06. doi: 10.1172/JCI27291. PubMed PMID: 16395396.

74. Xiao CY, Hara A, Yuhki K, Fujino T, Ma H, Okada Y, et al. Roles of prostaglandin I(2) and thromboxane $\mathrm{A}(2)$ in cardiac ischemia-reperfusion injury: a study using mice lacking their respective receptors. Circulation. 2001;104(18):2210-5. Epub 2001/10/31. PubMed PMID: 11684633 .

75. Degousee N, Fazel S, Angoulvant D, Stefanski E, Pawelzik SC, Korotkova M, et al. Microsomal prostaglandin E2 synthase-1 deletion leads to adverse left ventricular remodeling after myocardial infarction. Circulation. 2008;117(13):1701-10. Epub 2008/03/19. doi: CIRCULATIONAHA.107.749739 [pii]

10.1161/CIRCULATIONAHA.107.749739. PubMed PMID: 18347209. 
76. Qian JY, Harding P, Liu Y, Shesely E, Yang XP, LaPointe MC. Reduced cardiac remodeling and function in cardiac-specific EP4 receptor knockout mice with myocardial infarction. Hypertension. 2008;51(2):560-6. Epub 2008/01/09. doi: HYPERTENSIONAHA.107.102590 [pii]

\subsection{1/HYPERTENSIONAHA.107.102590. PubMed PMID: 18180401.}

77. Bunting S, Moncada S, Vane JR. The prostacyclin--thromboxane A2 balance: pathophysiological and therapeutic implications. Br Med Bull. 1983;39(3):271-6. Epub 1983/07/01. PubMed PMID: 6354352.

78. FitzGerald GA. COX-2 and beyond: Approaches to prostaglandin inhibition in human disease. Nat Rev Drug Discov. 2003;2(11):879-90. Epub 2003/12/12. doi: 10.1038/nrd1225

nrd1225 [pii]. PubMed PMID: 14668809.

79. de Nucci G, Gryglewski RJ, Warner TD, Vane JR. Receptor-mediated release of endothelium-derived relaxing factor and prostacyclin from bovine aortic endothelial cells is coupled. Proc Natl Acad Sci U S A. 1988;85(7):2334-8. Epub 1988/04/01. PubMed PMID: 2832851.

80. Palmer RM, Ferrige AG, Moncada S. Nitric oxide release accounts for the biological activity of endothelium-derived relaxing factor. Nature. 1987;327(6122):524-6. Epub 1987/06/11. doi: 10.1038/327524a0. PubMed PMID: 3495737.

81. Ellis EF, Oelz O, Roberts LJ, 2nd, Payne NA, Sweetman BJ, Nies AS, et al. Coronary arterial smooth muscle contraction by a substance released from platelets: evidence that it is thromboxane A2. Science. 1976;193(4258):1135-7. Epub 1976/09/17. PubMed PMID: 959827. 
82. Hamberg M, Svensson J, Samuelsson B. Thromboxanes: a new group of biologically active compounds derived from prostaglandin endoperoxides. Proc Natl Acad Sci U S A. 1975;72(8):2994-8. Epub 1975/08/01. PubMed PMID: 1059088.

83. Salzman PM, Salmon JA, Moncada S. Prostacyclin and thromboxane A2 synthesis by rabbit pulmonary artery. J Pharmacol Exp Ther. 1980;215(1):240-7. Epub 1980/10/01. PubMed PMID: 7005425.

84. Rocca B, Secchiero P, Ciabattoni G, Ranelletti FO, Catani L, Guidotti L, et al. Cyclooxygenase-2 expression is induced during human megakaryopoiesis and characterizes newly formed platelets. Proc Natl Acad Sci U S A. 2002;99(11):7634-9. PubMed PMID: 12032335.

85. Aronoff DM, Carstens JK, Chen GH, Toews GB, Peters-Golden M. Short communication: differences between macrophages and dendritic cells in the cyclic AMPdependent regulation of lipopolysaccharide-induced cytokine and chemokine synthesis. J Interferon Cytokine Res. 2006;26(11):827-33. PubMed PMID: 17115901.

86. Luo M, Jones SM, Phare SM, Coffey MJ, Peters-Golden M, Brock TG. Protein kinase A inhibits leukotriene synthesis by phosphorylation of 5-lipoxygenase on serine 523. J Biol Chem. 2004;279(40):41512-20. PubMed PMID: 15280375.

87. van der Pouw Kraan TC, van Lier RA, Aarden LA. PGE2 and the immune response. A central role for prostaglandin E2 in downregulating the inflammatory immune response. Mol Med Today. 1995;1(2):61. PubMed PMID: 17607896.

88. Aronoff DM, Canetti C, Peters-Golden M. Prostaglandin E2 inhibits alveolar macrophage phagocytosis through an E-prostanoid 2 receptor-mediated increase in intracellular cyclic AMP. J Immunol. 2004;173(1):559-65. Epub 2004/06/24. PubMed PMID: 15210817. 
89. Rossi AG, McCutcheon JC, Roy N, Chilvers ER, Haslett C, Dransfield I. Regulation of macrophage phagocytosis of apoptotic cells by cAMP. J Immunol. 1998;160(7):3562-8. PubMed PMID: 9531319.

90. Serezani CH, Chung J, Ballinger MN, Moore BB, Aronoff DM, Peters-Golden M. Prostaglandin E2 suppresses bacterial killing in alveolar macrophages by inhibiting NADPH oxidase. Am J Respir Cell Mol Biol. 2007;37(5):562-70. Epub 2007/06/23. doi: 10.1165/rcmb.2007-0153OC. PubMed PMID: 17585108; PubMed Central PMCID: PMC2048683.

91. Soares AC, Souza DG, Pinho V, Vieira AT, Barsante MM, Nicoli JR, et al. Impaired host defense to Klebsiella pneumoniae infection in mice treated with the PDE4 inhibitor rolipram. $\mathrm{Br}$ J Pharmacol. 2003;140(5):855-62. Epub 2003/10/31. doi: 10.1038/sj.bjp.0705517

140/5/855 [pii]. PubMed PMID: 14585803.

92. Weinberg DA, Weston LK, Kaplan JE. Influence of prostaglandin I2 on fibronectinmediated phagocytosis in vivo and in vitro. J Leukoc Biol. 1985;37(2):151-9. PubMed PMID: 2981944.

93. Ydrenius L, Majeed M, Rasmusson BJ, Stendahl O, Sarndahl E. Activation of cAMPdependent protein kinase is necessary for actin rearrangements in human neutrophils during phagocytosis. J Leukoc Biol. 2000;67(4):520-8. PubMed PMID: 10770285.

94. Aronoff DM, Peres CM, Serezani CH, Ballinger MN, Carstens JK, Coleman N, et al. Synthetic prostacyclin analogs differentially regulate macrophage function via distinct analog-receptor binding specificities. J Immunol. 2007;178(3):1628-34. PubMed PMID: 17237412. 
95. Brandwein SR. Regulation of interleukin 1 production by mouse peritoneal macrophages. Effects of arachidonic acid metabolites, cyclic nucleotides, and interferons. J Biol Chem. 1986;261(19):8624-32. Epub 1986/07/05. PubMed PMID: 2424900.

96. Kunkel SL, Spengler M, May MA, Spengler R, Larrick J, Remick D. Prostaglandin E2 regulates macrophage-derived tumor necrosis factor gene expression. J Biol Chem. 1988;263(11):5380-4. PubMed PMID: 3162731.

97. Kunkel SL, Wiggins RC, Chensue SW, Larrick J. Regulation of macrophage tumor necrosis factor production by prostaglandin E2. Biochem Biophys Res Commun. 1986;137(1):404-10. PubMed PMID: 3459461.

98. Takayama K, Garcia-Cardena G, Sukhova GK, Comander J, Gimbrone MA, Jr., Libby P. Prostaglandin E2 suppresses chemokine production in human macrophages through the EP4 receptor. J Biol Chem. 2002;277(46):44147-54. Epub 2002/09/07. doi: 10.1074/jbc.M204810200

M204810200 [pii]. PubMed PMID: 12215436.

99. van der Pouw Kraan TC, Boeije LC, Snijders A, Smeenk RJ, Wijdenes J, Aarden LA. Regulation of IL-12 production by human monocytes and the influence of prostaglandin E2. Ann N Y Acad Sci. 1996;795:147-57. Epub 1996/10/31. PubMed PMID: 8958925.

100. Xu XJ, Reichner JS, Mastrofrancesco B, Henry WL, Jr., Albina JE. Prostaglandin E2 suppresses lipopolysaccharide-stimulated IFN-beta production. J Immunol. 2008;180(4):2125-31. PubMed PMID: 18250418.

101. Harizi H, Juzan M, Pitard V, Moreau JF, Gualde N. Cyclooxygenase-2-issued prostaglandin $\mathrm{e}(2)$ enhances the production of endogenous IL-10, which down-regulates dendritic cell functions. J Immunol. 2002;168(5):2255-63. Epub 2002/02/23. PubMed PMID: 11859113. 
102. Hinson RM, Williams JA, Shacter E. Elevated interleukin 6 is induced by prostaglandin E2 in a murine model of inflammation: possible role of cyclooxygenase-2. Proc Natl Acad Sci U S A. 1996;93(10):4885-90. Epub 1996/05/14. PubMed PMID: 8643498.

103. Starczewski M, Voigtmann R, Peskar BA, Peskar BM. Plasma levels of 15-keto13,14-dihydro-prostaglandin E2 in patients with bronchogenic carcinoma. Prostaglandins Leukot Med. 1984;13(3):249-58. PubMed PMID: 6585845.

104. Hayek MG, Mura C, Wu D, Beharka AA, Han SN, Paulson KE, et al. Enhanced expression of inducible cyclooxygenase with age in murine macrophages. J Immunol. 1997;159(5):2445-51. PubMed PMID: 9278337.

105. Medjane S, Raymond B, Wu Y, Touqui L. Impact of CFTR DeltaF508 mutation on prostaglandin E2 production and type IIA phospholipase A2 expression by pulmonary epithelial cells. Am J Physiol Lung Cell Mol Physiol. 2005;289(5):L816-24. PubMed PMID: 15964894.

106. Strandvik B, Svensson E, Seyberth HW. Prostanoid biosynthesis in patients with cystic fibrosis. Prostaglandins Leukot Essent Fatty Acids. 1996;55(6):419-25. PubMed PMID: 9014220.

107. Levy BD, Clish CB, Schmidt B, Gronert K, Serhan CN. Lipid mediator class switching during acute inflammation: signals in resolution. Nat Immunol. 2001;2(7):612-9. PubMed PMID: 11429545.

108. Hong S, Gronert K, Devchand PR, Moussignac RL, Serhan CN. Novel docosatrienes and 17S-resolvins generated from docosahexaenoic acid in murine brain, human blood, and glial cells. Autacoids in anti-inflammation. J Biol Chem. 2003;278(17):14677-87. PubMed PMID: 12590139.

109. Marcheselli VL, Hong S, Lukiw WJ, Tian XH, Gronert K, Musto A, et al. Novel docosanoids inhibit brain ischemia-reperfusion-mediated leukocyte infiltration and pro- 
inflammatory gene expression. J Biol Chem. 2003;278(44):43807-17. Epub 2003/08/19. doi: 10.1074/jbc.M305841200

M305841200 [pii]. PubMed PMID: 12923200.

110. Serhan CN, Clish CB, Brannon J, Colgan SP, Chiang N, Gronert K. Novel functional sets of lipid-derived mediators with antiinflammatory actions generated from omega-3 fatty acids via cyclooxygenase 2-nonsteroidal antiinflammatory drugs and transcellular processing. J Exp Med. 2000;192(8):1197-204. PubMed PMID: 11034610.

111. Serhan CN, Hong S, Gronert K, Colgan SP, Devchand PR, Mirick G, et al. Resolvins: a family of bioactive products of omega-3 fatty acid transformation circuits initiated by aspirin treatment that counter proinflammation signals. J Exp Med. 2002;196(8):1025-37. PubMed PMID: 12391014.

112. Clark RB, Bishop-Bailey D, Estrada-Hernandez T, Hla T, Puddington L, Padula SJ. The nuclear receptor PPAR gamma and immunoregulation: PPAR gamma mediates inhibition of helper T cell responses. J Immunol. 2000;164(3):1364-71. PubMed PMID: 10640751.

113. Combs CK, Johnson DE, Karlo JC, Cannady SB, Landreth GE. Inflammatory mechanisms in Alzheimer's disease: inhibition of beta-amyloid-stimulated proinflammatory responses and neurotoxicity by PPARgamma agonists. J Neurosci. 2000;20(2):558-67. Epub 2000/01/13. PubMed PMID: 10632585.

114. Diab A, Deng C, Smith JD, Hussain RZ, Phanavanh B, Lovett-Racke AE, et al. Peroxisome proliferator-activated receptor-gamma agonist 15-deoxy-Delta(12,14)prostaglandin $\mathrm{J}(2)$ ameliorates experimental autoimmune encephalomyelitis. $\mathrm{J}$ Immunol. 2002;168(5):2508-15. PubMed PMID: 11859145. 
115. Kawahito Y, Kondo M, Tsubouchi Y, Hashiramoto A, Bishop-Bailey D, Inoue K, et al. 15-deoxy-delta(12,14)-PGJ(2) induces synoviocyte apoptosis and suppresses adjuvantinduced arthritis in rats. J Clin Invest. 2000;106(2):189-97. PubMed PMID: 10903334.

116. Reilly CM, Oates JC, Cook JA, Morrow JD, Halushka PV, Gilkeson GS. Inhibition of mesangial cell nitric oxide in MRL/lpr mice by prostaglandin $\mathrm{J} 2$ and proliferator activation receptor-gamma agonists. J Immunol. 2000;164(3):1498-504. Epub 2000/01/21. doi: ji_v164n3p1498 [pii]. PubMed PMID: 10640767.

117. Kim EH, Na HK, Surh YJ. Upregulation of VEGF by 15-deoxy-Delta12,14prostaglandin $\mathrm{J} 2$ via heme oxygenase-1 and ERK1/2 signaling in MCF-7 cells. Ann N Y Acad Sci. 2006;1090:375-84. Epub 2007/03/27. doi: 1090/1/375 [pii]

10.1196/annals.1378.041. PubMed PMID: 17384282.

118. Oliva JL, Perez-Sala D, Castrillo A, Martinez N, Canada FJ, Bosca L, et al. The cyclopentenone 15-deoxy-delta 12,14-prostaglandin J2 binds to and activates H-Ras. Proc Natl Acad Sci U S A. 2003;100(8):4772-7. Epub 2003/04/10. doi: 10.1073/pnas.0735842100

0735842100 [pii]. PubMed PMID: 12684535.

119. Renedo M, Gayarre J, Garcia-Dominguez CA, Perez-Rodriguez A, Prieto A, Canada FJ, et al. Modification and activation of Ras proteins by electrophilic prostanoids with different structure are site-selective. Biochemistry. 2007;46(22):6607-16. Epub 2007/05/11. doi: 10.1021/bi602389p. PubMed PMID: 17489560.

120. Khan MM. Regulation of IL-4 and IL-5 secretion by histamine and PGE2. Adv Exp Med Biol. 1995;383:35-42. Epub 1995/01/01. PubMed PMID: 8644511.

121. Jiang C, Ting AT, Seed B. PPAR-gamma agonists inhibit production of monocyte inflammatory cytokines. Nature. 1998;391(6662):82-6. PubMed PMID: 9422509. 
122. Ricote M, Li AC, Willson TM, Kelly CJ, Glass CK. The peroxisome proliferatoractivated receptor-gamma is a negative regulator of macrophage activation. Nature. 1998;391(6662):79-82. PubMed PMID: 9422508.

123. Cernuda-Morollon E, Pineda-Molina E, Canada FJ, Perez-Sala D. 15-Deoxy-Delta 12,14-prostaglandin $\mathrm{J} 2$ inhibition of NF-kappaB-DNA binding through covalent modification of the p50 subunit. J Biol Chem. 2001;276(38):35530-6. PubMed PMID: 11466314.

124. Rossi A, Kapahi P, Natoli G, Takahashi T, Chen Y, Karin M, et al. Anti-inflammatory cyclopentenone prostaglandins are direct inhibitors of IkappaB kinase. Nature. 2000;403(6765):103-8. PubMed PMID: 10638762.

125. Straus DS, Pascual G, Li M, Welch JS, Ricote M, Hsiang CH, et al. 15-deoxy-delta 12,14-prostaglandin J2 inhibits multiple steps in the NF-kappa B signaling pathway. Proc Natl Acad Sci U S A. 2000;97(9):4844-9. PubMed PMID: 10781090.

126. Jackson SM, Parhami F, Xi XP, Berliner JA, Hsueh WA, Law RE, et al. Peroxisome proliferator-activated receptor activators target human endothelial cells to inhibit leukocyteendothelial cell interaction. Arterioscler Thromb Vasc Biol. 1999;19(9):2094-104. Epub 1999/09/10. PubMed PMID: 10479650.

127. Pasceri V, Wu HD, Willerson JT, Yeh ET. Modulation of vascular inflammation in vitro and in vivo by peroxisome proliferator-activated receptor-gamma activators. Circulation. 2000;101(3):235-8. Epub 2000/01/25. PubMed PMID: 10645917.

128. Zhang X, Wang JM, Gong WH, Mukaida N, Young HA. Differential regulation of chemokine gene expression by 15-deoxy-delta 12,14 prostaglandin $\mathrm{J} 2$. J Immunol. 2001;166(12):7104-11. Epub 2001/06/08. PubMed PMID: 11390455.

129. Lawrence T. Modulation of inflammation in vivo through induction of the heat shock response, effects on NF-kappaB activation. Inflamm Res. 2002;51(2):108-9. Epub 2002/04/03. PubMed PMID: 11926310. 
130. Bishop-Bailey D, Hla T. Endothelial cell apoptosis induced by the peroxisome proliferator-activated receptor (PPAR) ligand 15-deoxy-Delta12, 14-prostaglandin J2. J Biol Chem. 1999;274(24):17042-8. Epub 1999/06/08. PubMed PMID: 10358055.

131. Khoshnan A, Tindell C, Laux I, Bae D, Bennett B, Nel AE. The NF-kappa B cascade is important in Bcl-xL expression and for the anti-apoptotic effects of the CD28 receptor in primary human CD4+ lymphocytes. J Immunol. 2000;165(4):1743-54. Epub 2000/08/05. doi: ji_v165n4p1743 [pii]. PubMed PMID: 10925251.

132. Lawrence T, Gilroy DW, Colville-Nash PR, Willoughby DA. Possible new role for NF-kappaB in the resolution of inflammation. Nat Med. 2001;7(12):1291-7. Epub 2001/12/01. doi: 10.1038/nm1201-1291

nm1201-1291 [pii]. PubMed PMID: 11726968.

133. Ward C, Dransfield I, Murray J, Farrow SN, Haslett C, Rossi AG. Prostaglandin D2 and its metabolites induce caspase-dependent granulocyte apoptosis that is mediated via inhibition of I kappa B alpha degradation using a peroxisome proliferator-activated receptorgamma-independent mechanism. J Immunol. 2002;168(12):6232-43. PubMed PMID: 12055237.

134. Trivedi SG, Newson J, Rajakariar R, Jacques TS, Hannon R, Kanaoka Y, et al. Essential role for hematopoietic prostaglandin D2 synthase in the control of delayed type hypersensitivity. Proc Natl Acad Sci U S A. 2006;103(13):5179-84. PubMed PMID: 16547141.

135. Lewis RA, Austen KF, Drazen JM, Clark DA, Marfat A, Corey EJ. Slow reacting substances of anaphylaxis: identification of leukotrienes C-1 and D from human and rat sources. Proc Natl Acad Sci U S A. 1980;77(6):3710-4. Epub 1980/06/01. PubMed PMID: 6106193. 
136. Borgeat P, Samuelsson B. Arachidonic acid metabolism in polymorphonuclear leukocytes: effects of ionophore A23187. Proc Natl Acad Sci U S A. 1979;76(5):2148-52. Epub 1979/05/01. PubMed PMID: 377292.

137. Smith MJ. Prostaglandins and the polymorphonuclear leucocyte. Agents Actions Suppl. 1979(6):91-103. Epub 1979/01/01. PubMed PMID: 230732.

138. Funk CD. Prostaglandins and leukotrienes: advances in eicosanoid biology. Science. 2001;294(5548):1871-5. Epub 2001/12/01. doi: 10.1126/science.294.5548.1871

294/5548/1871 [pii]. PubMed PMID: 11729303.

139. Minami M, Ohno S, Kawasaki H, Radmark O, Samuelsson B, Jornvall H, et al. Molecular cloning of a cDNA coding for human leukotriene A4 hydrolase. Complete primary structure of an enzyme involved in eicosanoid synthesis. J Biol Chem. 1987;262(29):13873-6. Epub 1987/10/15. PubMed PMID: 3654641.

140. Hammarstrom S, Orning L, Bernstrom K. Metabolism of leukotrienes. Mol Cell Biochem. 1985;69(1):7-16. Epub 1985/11/01. PubMed PMID: 3001504.

141. Lam BK, Gagnon L, Austen KF, Soberman RJ. The mechanism of leukotriene B4 export from human polymorphonuclear leukocytes. J Biol Chem. 1990;265(23):13438-41. Epub 1990/08/15. PubMed PMID: 2166027.

142. Leier I, Jedlitschky G, Buchholz U, Keppler D. Characterization of the ATPdependent leukotriene $\mathrm{C} 4$ export carrier in mastocytoma cells. Eur $\mathrm{J}$ Biochem. 1994;220(2):599-606. Epub 1994/03/01. PubMed PMID: 8125120.

143. Rouzer CA, Samuelsson B. On the nature of the 5-lipoxygenase reaction in human leukocytes: enzyme purification and requirement for multiple stimulatory factors. Proc Natl Acad Sci U S A. 1985;82(18):6040-4. Epub 1985/09/01. PubMed PMID: 3929248. 
144. Ochi K, Yoshimoto T, Yamamoto S, Taniguchi K, Miyamoto T. Arachidonate 5lipoxygenase of guinea pig peritoneal polymorphonuclear leukocytes. Activation by adenosine 5'-triphosphate. J Biol Chem. 1983;258(9):5754-8. Epub 1983/05/10. PubMed PMID: 6406506.

145. Werz O, Szellas D, Steinhilber D, Radmark O. Arachidonic acid promotes phosphorylation of 5-lipoxygenase at Ser-271 by MAPK-activated protein kinase 2 (MK2). J Biol Chem. 2002;277(17):14793-800. Epub 2002/02/15. doi: 10.1074/jbc.M111945200

M111945200 [pii]. PubMed PMID: 11844797.

146. Kanaoka Y, Boyce JA. Cysteinyl leukotrienes and their receptors: cellular distribution and function in immune and inflammatory responses. J Immunol. 2004;173(3):1503-10. Epub 2004/07/22. doi: 173/3/1503 [pii]. PubMed PMID: 15265876.

147. Tager AM, Luster AD. BLT1 and BLT2: the leukotriene B(4) receptors. Prostaglandins Leukot Essent Fatty Acids. 2003;69(2-3):123-34. Epub 2003/08/05. doi: S0952327803000735 [pii]. PubMed PMID: 12895595.

148. Lynch KR, O'Neill GP, Liu Q, Im DS, Sawyer N, Metters KM, et al. Characterization of the human cysteinyl leukotriene CysLT1 receptor. Nature. 1999;399(6738):789-93. Epub 1999/07/03. doi: 10.1038/21658. PubMed PMID: 10391245.

149. Beller TC, Friend DS, Maekawa A, Lam BK, Austen KF, Kanaoka Y. Cysteinyl leukotriene 1 receptor controls the severity of chronic pulmonary inflammation and fibrosis. Proc Natl Acad Sci U S A. 2004;101(9):3047-52. Epub 2004/02/19. doi: 10.1073/pnas.0400235101

0400235101 [pii]. PubMed PMID: 14970333.

150. Hui Y, Cheng Y, Smalera I, Jian W, Goldhahn L, Fitzgerald GA, et al. Directed vascular expression of human cysteinyl leukotriene 2 receptor modulates endothelial 
permeability and systemic blood pressure. Circulation. 2004;110(21):3360-6. Epub 2004/11/17. doi: 01.CIR.0000147775.50954.AA [pii]

10.1161/01.CIR.0000147775.50954.AA. PubMed PMID: 15545522.

151. Sousa AR, Parikh A, Scadding G, Corrigan CJ, Lee TH. Leukotriene-receptor expression on nasal mucosal inflammatory cells in aspirin-sensitive rhinosinusitis. $\mathrm{N}$ Engl $\mathbf{J}$ Med. 2002;347(19):1493-9. Epub 2002/11/08. doi: 10.1056/NEJMoa013508

347/19/1493 [pii]. PubMed PMID: 12421891.

152. Devchand PR, Keller H, Peters JM, Vazquez M, Gonzalez FJ, Wahli W. The PPARalpha-leukotriene B4 pathway to inflammation control. Nature. 1996;384(6604):39-43. Epub 1996/11/07. doi: 10.1038/384039a0. PubMed PMID: 8900274.

153. Krey G, Braissant O, L'Horset F, Kalkhoven E, Perroud M, Parker MG, et al. Fatty acids, eicosanoids, and hypolipidemic agents identified as ligands of peroxisome proliferatoractivated receptors by coactivator-dependent receptor ligand assay. Mol Endocrinol. 1997;11(6):779-91. Epub 1997/06/01. PubMed PMID: 9171241.

154. Lin Q, Ruuska SE, Shaw NS, Dong D, Noy N. Ligand selectivity of the peroxisome proliferator-activated receptor alpha. Biochemistry. 1999;38(1):185-90. Epub 1999/01/16. doi: 10.1021/bi9816094

bi9816094 [pii]. PubMed PMID: 9890897.

155. Narala VR, Adapala RK, Suresh MV, Brock TG, Peters-Golden M, Reddy RC. Leukotriene B4 is a physiologically relevant endogenous peroxisome proliferator-activated receptor-\{alpha\} agonist. J Biol Chem. Epub 2010/04/20. doi: M109.085118 [pii]

10.1074/jbc.M109.085118. PubMed PMID: 20400503. 
156. Borgeat P, Naccache PH. Biosynthesis and biological activity of leukotriene B4. Clin Biochem. 1990;23(5):459-68. Epub 1990/10/01. doi: 0009-9120(90)90272-V [pii]. PubMed PMID: 2174753.

157. Ott VL, Cambier JC, Kappler J, Marrack P, Swanson BJ. Mast cell-dependent migration of effector $\mathrm{CD} 8+\mathrm{T}$ cells through production of leukotriene $\mathrm{B} 4$. Nat Immunol. 2003;4(10):974-81. Epub 2003/09/02. doi: 10.1038/ni971

ni971 [pii]. PubMed PMID: 12949532.

158. Woodward DF, Krauss AH, Nieves AL, Spada CS. Studies on leukotriene D4 as an eosinophil chemoattractant. Drugs Exp Clin Res. 1991;17(12):543-8. Epub 1991/01/01. PubMed PMID: 1841046.

159. Bjork J, Hedqvist P, Arfors KE. Increase in vascular permeability induced by leukotriene B4 and the role of polymorphonuclear leukocytes. Inflammation. 1982;6(2):189200. Epub 1982/06/01. PubMed PMID: 6179872.

160. Dahlen SE, Bjork J, Hedqvist P, Arfors KE, Hammarstrom S, Lindgren JA, et al. Leukotrienes promote plasma leakage and leukocyte adhesion in postcapillary venules: in vivo effects with relevance to the acute inflammatory response. Proc Natl Acad Sci U S A. 1981;78(6):3887-91. Epub 1981/06/01. PubMed PMID: 6267608.

161. Hedqvist P, Dahlen SE. Pulmonary and vascular effects of leukotrienes imply involvement in asthma and inflammation. Adv Prostaglandin Thromboxane Leukot Res. 1983;11:27-32. Epub 1983/01/01. PubMed PMID: 6221536.

162. Orange RP, Stechschulte DJ, Austen KF. Cellular mechanisms involved in the release of slow reacting substance of anaphylaxis. Fed Proc. 1969;28(5):1710-5. Epub 1969/09/01. PubMed PMID: 4185891. 
163. Svensjo E. Bradykinin and prostaglandin E1, E2 and F2alpha-induced macromolecular leakage in the hamster cheek pouch. Prostaglandins Med. 1978;1(5):397-410. Epub 1978/11/01. PubMed PMID: 724817.

164. Werz O, Steinhilber D. Development of 5-lipoxygenase inhibitors--lessons from cellular enzyme regulation. Biochem Pharmacol. 2005;70(3):327-33. Epub 2005/05/24. doi: S0006-2952(05)00202-9 [pii]

10.1016/j.bcp.2005.04.018. PubMed PMID: 15907806.

165. Israel E, Rubin P, Kemp JP, Grossman J, Pierson W, Siegel SC, et al. The effect of inhibition of 5-lipoxygenase by zileuton in mild-to-moderate asthma. Ann Intern Med. 1993;119(11):1059-66. Epub 1993/12/01. PubMed PMID: 8239223.

166. Knorr B, Matz J, Bernstein JA, Nguyen H, Seidenberg BC, Reiss TF, et al. Montelukast for chronic asthma in 6- to 14-year-old children: a randomized, double-blind trial. Pediatric Montelukast Study Group. JAMA. 1998;279(15):1181-6. Epub 1998/04/29. doi: joc71519 [pii]. PubMed PMID: 9555757.

167. Suissa S, Dennis R, Ernst P, Sheehy O, Wood-Dauphinee S. Effectiveness of the leukotriene receptor antagonist zafirlukast for mild-to-moderate asthma. A randomized, double-blind, placebo-controlled trial. Ann Intern Med. 1997;126(3):177-83. Epub 1997/02/01. PubMed PMID: 9027267.

168. Spanbroek R, Grabner R, Lotzer K, Hildner M, Urbach A, Ruhling K, et al. Expanding expression of the 5-lipoxygenase pathway within the arterial wall during human atherogenesis. Proc Natl Acad Sci U S A. 2003;100(3):1238-43. Epub 2003/01/29. doi: 10.1073/pnas.242716099

242716099 [pii]. PubMed PMID: 12552108. 
169. Qiu H, Gabrielsen A, Agardh HE, Wan M, Wetterholm A, Wong CH, et al. Expression of 5-lipoxygenase and leukotriene A4 hydrolase in human atherosclerotic lesions correlates with symptoms of plaque instability. Proc Natl Acad Sci U S A. 2006;103(21):8161-6. Epub 2006/05/16. doi: 0602414103 [pii]

10.1073/pnas.0602414103. PubMed PMID: 16698924.

170. Aiello RJ, Bourassa PA, Lindsey S, Weng W, Freeman A, Showell HJ. Leukotriene B4 receptor antagonism reduces monocytic foam cells in mice. Arterioscler Thromb Vasc Biol. 2002;22(3):443-9. Epub 2002/03/09. PubMed PMID: 11884288.

171. Back M, Bu DX, Branstrom R, Sheikine Y, Yan ZQ, Hansson GK. Leukotriene B4 signaling through NF-kappaB-dependent BLT1 receptors on vascular smooth muscle cells in atherosclerosis and intimal hyperplasia. Proc Natl Acad Sci U S A. 2005;102(48):17501-6. Epub 2005/11/19. doi: 0505845102 [pii]

10.1073/pnas.0505845102. PubMed PMID: 16293697.

172. Uzonyi B, Lotzer K, Jahn S, Kramer C, Hildner M, Bretschneider E, et al. Cysteinyl leukotriene 2 receptor and protease-activated receptor 1 activate strongly correlated early genes in human endothelial cells. Proc Natl Acad Sci U S A. 2006;103(16):6326-31. Epub 2006/04/12. doi: 0601223103 [pii]

10.1073/pnas.0601223103. PubMed PMID: 16606835.

173. Zhao L, Moos MP, Grabner R, Pedrono F, Fan J, Kaiser B, et al. The 5-lipoxygenase pathway promotes pathogenesis of hyperlipidemia-dependent aortic aneurysm. Nat Med. 2004;10(9):966-73. Epub 2004/08/24. doi: 10.1038/nm1099

nm1099 [pii]. PubMed PMID: 15322539. 
174. Helgadottir A, Manolescu A, Helgason A, Thorleifsson G, Thorsteinsdottir U, Gudbjartsson DF, et al. A variant of the gene encoding leukotriene A4 hydrolase confers ethnicity-specific risk of myocardial infarction. Nat Genet. 2006;38(1):68-74. Epub 2005/11/12. doi: ng1692 [pii]

10.1038/ng1692. PubMed PMID: 16282974.

175. Helgadottir A, Manolescu A, Thorleifsson G, Gretarsdottir S, Jonsdottir H, Thorsteinsdottir U, et al. The gene encoding 5-lipoxygenase activating protein confers risk of myocardial infarction and stroke. Nat Genet. 2004;36(3):233-9. Epub 2004/02/11. doi: $10.1038 /$ ng 1311

ng1311 [pii]. PubMed PMID: 14770184.

176. Kajimoto K, Shioji K, Ishida C, Iwanaga Y, Kokubo Y, Tomoike H, et al. Validation of the association between the gene encoding 5-lipoxygenase-activating protein and myocardial infarction in a Japanese population. Circ J. 2005;69(9):1029-34. Epub 2005/08/30. doi: JST.JSTAGE/circj/69.1029 [pii]. PubMed PMID: 16127181.

177. Hakonarson H, Thorvaldsson S, Helgadottir A, Gudbjartsson D, Zink F, Andresdottir M, et al. Effects of a 5-lipoxygenase-activating protein inhibitor on biomarkers associated with risk of myocardial infarction: a randomized trial. JAMA. 2005;293(18):2245-56. Epub 2005/05/12. doi: 293/18/2245 [pii]

10.1001/jama.293.18.2245. PubMed PMID: 15886380.

178. Peters-Golden M, Canetti C, Mancuso P, Coffey MJ. Leukotrienes: underappreciated mediators of innate immune responses. J Immunol. 2005;174(2):589-94. Epub 2005/01/07. doi: 174/2/589 [pii]. PubMed PMID: 15634873.

179. Bailie MB, Standiford TJ, Laichalk LL, Coffey MJ, Strieter R, Peters-Golden M. Leukotriene-deficient mice manifest enhanced lethality from Klebsiella pneumonia in 
association with decreased alveolar macrophage phagocytic and bactericidal activities. J Immunol. 1996;157(12):5221-4. PubMed PMID: 8955165.

180. Mancuso P, Lewis C, Serezani CH, Goel D, Peters-Golden M. Intrapulmonary administration of leukotriene B4 enhances pulmonary host defense against pneumococcal pneumonia. Infect Immun.78(5):2264-71. Epub 2010/03/17. doi: IAI.01323-09 [pii]

10.1128/IAI.01323-09. PubMed PMID: 20231413.

181. Medeiros AI, Sa-Nunes A, Turato WM, Secatto A, Frantz FG, Sorgi CA, et al. Leukotrienes are potent adjuvant during fungal infection: effects on memory $\mathrm{T}$ cells. $\mathrm{J}$ Immunol. 2008;181(12):8544-51. Epub 2008/12/04. doi: 181/12/8544 [pii]. PubMed PMID: 19050273.

182. Peres CM, de Paula L, Medeiros AI, Sorgi CA, Soares EG, Carlos D, et al. Inhibition of leukotriene biosynthesis abrogates the host control of Mycobacterium tuberculosis. Microbes Infect. 2007;9(4):483-9. Epub 2007/03/10. doi: S1286-4579(07)00037-8 [pii]

10.1016/j.micinf.2007.01.006. PubMed PMID: 17347013.

183. Schultz MJ, Wijnholds J, Peppelenbosch MP, Vervoordeldonk MJ, Speelman P, van Deventer SJ, et al. Mice lacking the multidrug resistance protein 1 are resistant to Streptococcus pneumoniae-induced pneumonia. J Immunol. 2001;166(6):4059-64. PubMed PMID: 11238654.

184. Serezani CH, Perrela JH, Russo M, Peters-Golden M, Jancar S. Leukotrienes are essential for the control of Leishmania amazonensis infection and contribute to strain variation in susceptibility. J Immunol. 2006;177(5):3201-8. Epub 2006/08/22. doi: 177/5/3201 [pii]. PubMed PMID: 16920959.

185. Serezani CH, Aronoff DM, Jancar S, Mancuso P, Peters-Golden M. Leukotrienes enhance the bactericidal activity of alveolar macrophages against Klebsiella pneumoniae 
through the activation of NADPH oxidase. Blood. 2005;106(3):1067-75. PubMed PMID: 15718414.

186. Ballinger MN, Hubbard LL, McMillan TR, Toews GB, Peters-Golden M, Paine R, 3rd, et al. Paradoxical role of alveolar macrophage-derived granulocyte-macrophage colonystimulating factor in pulmonary host defense post-bone marrow transplantation. Am J Physiol Lung Cell Mol Physiol. 2008;295(1):L114-22. Epub 2008/05/06. doi: 00309.2007 [pii]

10.1152/ajplung.00309.2007. PubMed PMID: 18456799.

187. Balter MS, Toews GB, Peters-Golden M. Multiple defects in arachidonate metabolism in alveolar macrophages from young asymptomatic smokers. $\mathbf{J}$ Lab Clin Med. 1989;114(6):662-73. Epub 1989/12/01. doi: 0022-2143(89)90132-7 [pii]. PubMed PMID: 2512364.

188. Cederholm T, Lindgren JA, Palmblad J. Impaired leukotriene C4 generation in granulocytes from protein-energy malnourished chronically ill elderly. J Intern Med. 2000;247(6):715-22. Epub 2000/07/08. doi: jim691 [pii]. PubMed PMID: 10886494.

189. Coffey MJ, Phare SM, Kazanjian PH, Peters-Golden M. 5-Lipoxygenase metabolism in alveolar macrophages from subjects infected with the human immunodeficiency virus. $\mathbf{J}$ Immunol. 1996;157(1):393-9. Epub 1996/07/01. PubMed PMID: 8683143.

190. Coffey MJ, Wilcoxen SE, Phare SM, Simpson RU, Gyetko MR, Peters-Golden M. Reduced 5-lipoxygenase metabolism of arachidonic acid in macrophages rrom 1,25dihydroxyvitamin D3-deficient rats. Prostaglandins. 1994;48(5):313-29. Epub 1994/11/01. PubMed PMID: 7855310.

191. Jubiz W, Draper RE, Gale J, Nolan G. Decreased leukotriene B4 synthesis by polymorphonuclear leukocytes from male patients with diabetes mellitus. Prostaglandins Leukot Med. 1984;14(3):305-11. Epub 1984/06/01. PubMed PMID: 6087366. 
192. Larfars G, Lantoine F, Devynck MA, Palmblad J, Gyllenhammar H. Activation of nitric oxide release and oxidative metabolism by leukotrienes B4, C4, and D4 in human polymorphonuclear leukocytes. Blood. 1999;93(4):1399-405. PubMed PMID: 9949184.

193. Talvani A, Machado FS, Santana GC, Klein A, Barcelos L, Silva JS, et al. Leukotriene B(4) induces nitric oxide synthesis in Trypanosoma cruzi-infected murine macrophages and mediates resistance to infection. Infect Immun. 2002;70(8):4247-53. PubMed PMID: 12117933.

194. Flamand L, Tremblay MJ, Borgeat P. Leukotriene B4 triggers the in vitro and in vivo release of potent antimicrobial agents. J Immunol. 2007;178(12):8036-45. Epub 2007/06/06. doi: 178/12/8036 [pii]. PubMed PMID: 17548641.

195. Powell WS, Gravelle F, Gravel S. Metabolism of 5(S)-hydroxy-6,8,11,14eicosatetraenoic acid and other 5(S)-hydroxyeicosanoids by a specific dehydrogenase in human polymorphonuclear leukocytes. J Biol Chem. 1992;267(27):19233-41. Epub 1992/09/25. PubMed PMID: 1326548.

196. Graham FD, Erlemann KR, Gravel S, Rokach J, Powell WS. Oxidative stress-induced changes in pyridine nucleotides and chemoattractant 5-lipoxygenase products in aging neutrophils. Free Radic Biol Med. 2009;47(1):62-71. Epub 2009/04/21. doi: S08915849(09)00200-7 [pii]

10.1016/j.freeradbiomed.2009.04.016. PubMed PMID: 19376220.

197. Powell WS, Gravelle F, Gravel S. Phorbol myristate acetate stimulates the formation of 5-oxo-6,8,11,14-eicosatetraenoic acid by human neutrophils by activating NADPH oxidase. J Biol Chem. 1994;269(41):25373-80. Epub 1994/10/14. PubMed PMID: 7929234.

198. Cossette C, Patel P, Anumolu JR, Sivendran S, Lee GJ, Gravel S, et al. Human neutrophils convert the sebum-derived polyunsaturated fatty acid Sebaleic acid to a potent 
granulocyte chemoattractant. J Biol Chem. 2008;283(17):11234-43. Epub 2008/02/22. doi: M709531200 [pii]

10.1074/jbc.M709531200. PubMed PMID: 18287092.

199. Patel P, Cossette C, Anumolu JR, Gravel S, Lesimple A, Mamer OA, et al. Structural requirements for activation of the 5-oxo-6E,8Z, 11Z,14Z-eicosatetraenoic acid (5-oxo-ETE) receptor: identification of a mead acid metabolite with potent agonist activity. $\mathrm{J}$ Pharmacol Exp Ther. 2008;325(2):698-707. Epub 2008/02/23. doi: jpet.107.134908 [pii]

10.1124/jpet.107.134908. PubMed PMID: 18292294.

200. Powell WS, Chung D, Gravel S. 5-Oxo-6,8,11,14-eicosatetraenoic acid is a potent stimulator of human eosinophil migration. J Immunol. 1995;154(8):4123-32. Epub 1995/04/15. PubMed PMID: 7706749.

201. Powell WS, Rokach J. Biochemistry, biology and chemistry of the 5-lipoxygenase product 5-oxo-ETE. Prog Lipid Res. 2005;44(2-3):154-83. Epub 2005/05/17. doi: S01637827(05)00013-5 [pii]

10.1016/j.plipres.2005.04.002. PubMed PMID: 15893379.

202. Brink CB, Harvey BH, Bodenstein J, Venter DP, Oliver DW. Recent advances in drug action and therapeutics: relevance of novel concepts in G-protein-coupled receptor and signal transduction pharmacology. Br J Clin Pharmacol. 2004;57(4):373-87. Epub 2004/03/18. doi: 10.1111/j.1365-2125.2003.02046.x

BCP2046 [pii]. PubMed PMID: 15025734.

203. Takeda S, Kadowaki S, Haga T, Takaesu H, Mitaku S. Identification of G proteincoupled receptor genes from the human genome sequence. FEBS Lett. 2002;520(1-3):97-101. Epub 2002/06/05. doi: S0014579302027758 [pii]. PubMed PMID: 12044878. 
204. Hosoi T, Koguchi Y, Sugikawa E, Chikada A, Ogawa K, Tsuda N, et al. Identification of a novel human eicosanoid receptor coupled to G(i/o). J Biol Chem. 2002;277(35):3145965. Epub 2002/06/18. doi: 10.1074/jbc.M203194200

M203194200 [pii]. PubMed PMID: 12065583.

205. Jones CE, Holden S, Tenaillon L, Bhatia U, Seuwen K, Tranter P, et al. Expression and characterization of a 5-oxo-6E,8Z,11Z,14Z-eicosatetraenoic acid receptor highly expressed on human eosinophils and neutrophils. Mol Pharmacol. 2003;63(3):471-7. Epub 2003/02/28. PubMed PMID: 12606753.

206. Norgauer J, Barbisch M, Czech W, Pareigis J, Schwenk U, Schroder JM. Chemotactic 5-oxo-icosatetraenoic acids activate a unique pattern of neutrophil responses. Analysis of phospholipid metabolism, intracellular $\mathrm{Ca} 2+$ transients, actin reorganization, superoxideanion production and receptor up-regulation. Eur J Biochem. 1996;236(3):1003-9. Epub 1996/03/15. PubMed PMID: 8665888.

207. O'Flaherty JT, Kuroki M, Nixon AB, Wijkander J, Yee E, Lee SL, et al. 5-Oxoeicosanoids and hematopoietic cytokines cooperate in stimulating neutrophil function and the mitogen-activated protein kinase pathway. J Biol Chem. 1996;271(30):17821-8. Epub 1996/07/26. PubMed PMID: 8663432.

208. Hosoi T, Sugikawa E, Chikada A, Koguchi Y, Ohnuki T. TG1019/OXE, a Galpha(i/o)-protein-coupled receptor, mediates 5-oxo-eicosatetraenoic acid-induced chemotaxis. Biochem Biophys Res Commun. 2005;334(4):987-95. Epub 2005/07/26. doi: S0006-291X(05)01437-3 [pii]

10.1016/j.bbrc.2005.06.191. PubMed PMID: 16039985.

209. O'Flaherty JT, Rogers LC, Chadwell BA, Owen JS, Rao A, Cramer SD, et al. 5(S)Hydroxy-6,8,11,14-E,Z,Z,Z-eicosatetraenoate stimulates PC3 cell signaling and growth by a 
receptor-dependent mechanism. Cancer Res. 2002;62(23):6817-9. Epub 2002/12/04. PubMed PMID: 12460891.

210. Langlois A, Chouinard F, Flamand N, Ferland C, Rola-Pleszczynski M, Laviolette M. Crucial implication of protein kinase C (PKC)-delta, PKC-zeta, ERK-1/2, and p38 MAPK in migration of human asthmatic eosinophils. J Leukoc Biol. 2009;85(4):656-63. Epub 2009/01/24. doi: jlb.0808492 [pii]

10.1189/jlb.0808492. PubMed PMID: 19164129.

211. O'Flaherty JT, Kuroki M, Nixon AB, Wijkander J, Yee E, Lee SL, et al. 5-Oxoeicosatetraenoate is a broadly active, eosinophil-selective stimulus for human granulocytes. $\mathbf{J}$ Immunol. 1996;157(1):336-42. Epub 1996/07/01. PubMed PMID: 8683135.

212. Stamatiou PB, Chan CC, Monneret G, Ethier D, Rokach J, Powell WS. 5-oxo6,8,11,14-eicosatetraenoic acid stimulates the release of the eosinophil survival factor granulocyte/macrophage colony-stimulating factor from monocytes. $\mathrm{J}$ Biol Chem. 2004;279(27):28159-64. Epub 2004/05/12. doi: 10.1074/jbc.M401537200

M401537200 [pii]. PubMed PMID: 15136573.

213. Ghosh S, Karin M. Missing pieces in the NF-kappaB puzzle. Cell. 2002;109 Suppl:S81-96. Epub 2002/05/02. doi: S0092867402007031 [pii]. PubMed PMID: 11983155.

214. Sundaram S, Ghosh J. Expression of 5-oxoETE receptor in prostate cancer cells: critical role in survival. Biochem Biophys Res Commun. 2006;339(1):93-8. Epub 2005/11/18. doi: S0006-291X(05)02498-8 [pii]

10.1016/j.bbrc.2005.10.189. PubMed PMID: 16289380.

215. Claria J, Serhan CN. Aspirin triggers previously undescribed bioactive eicosanoids by human endothelial cell-leukocyte interactions. Proc Natl Acad Sci U S A. 1995;92(21):94759. PubMed PMID: 7568157. 
216. Serhan CN. On the relationship between leukotriene and lipoxin production by human neutrophils: evidence for differential metabolism of 15-HETE and 5-HETE. Biochim Biophys Acta. 1989;1004(2):158-68. Epub 1989/08/08. PubMed PMID: 2546590.

217. Serhan CN. Leukocyte transmigration, chemotaxis, and oxygenated derivatives of arachidonic acid: when is chirality important? Am J Respir Cell Mol Biol. 1995;12(3):251-3. Epub 1995/03/01. PubMed PMID: 7873189.

218. Brezinski ME, Serhan CN. Selective incorporation of (15S)-hydroxyeicosatetraenoic acid in phosphatidylinositol of human neutrophils: agonist-induced deacylation and transformation of stored hydroxyeicosanoids. Proc Natl Acad Sci U S A. 1990;87(16):624852. PubMed PMID: 2117277.

219. Romano M, Serhan CN. Lipoxin generation by permeabilized human platelets. Biochemistry. 1992;31(35):8269-77. Epub 1992/09/08. PubMed PMID: 1381961.

220. Chiang N, Takano T, Arita M, Watanabe S, Serhan CN. A novel rat lipoxin A4 receptor that is conserved in structure and function. Br J Pharmacol. 2003;139(1):89-98. Epub 2003/05/15. doi: 10.1038/sj.bjp.0705220. PubMed PMID: 12746227; PubMed Central PMCID: PMC1573822.

221. Fiore S, Maddox JF, Perez HD, Serhan CN. Identification of a human cDNA encoding a functional high affinity lipoxin A4 receptor. J Exp Med. 1994;180(1):253-60. Epub 1994/07/01. PubMed PMID: 8006586.

222. Takano T, Fiore S, Maddox JF, Brady HR, Petasis NA, Serhan CN. Aspirin-triggered 15-epi-lipoxin A4 (LXA4) and LXA4 stable analogues are potent inhibitors of acute inflammation: evidence for anti-inflammatory receptors. J Exp Med. 1997;185(9):1693-704. Epub 1997/05/05. PubMed PMID: 9151906; PubMed Central PMCID: PMC2196289.

223. Maddox JF, Hachicha M, Takano T, Petasis NA, Fokin VV, Serhan CN. Lipoxin A4 stable analogs are potent mimetics that stimulate human monocytes and THP-1 cells via a G- 
protein-linked lipoxin A4 receptor. J Biol Chem. 1997;272(11):6972-8. Epub 1997/03/14. PubMed PMID: 9054386.

224. Ariel A, Chiang N, Arita M, Petasis NA, Serhan CN. Aspirin-triggered lipoxin A4 and B4 analogs block extracellular signal-regulated kinase-dependent TNF-alpha secretion from human T cells. J Immunol. 2003;170(12):6266-72. PubMed PMID: 12794159.

225. Sodin-Semrl S, Taddeo B, Tseng D, Varga J, Fiore S. Lipoxin A4 inhibits IL-1 betainduced IL-6, IL-8, and matrix metalloproteinase-3 production in human synovial fibroblasts and enhances synthesis of tissue inhibitors of metalloproteinases. $\mathrm{J}$ Immunol. 2000;164(5):2660-6. Epub 2000/02/29. doi: ji_v164n5p2660 [pii]. PubMed PMID: 10679106. 226. Gronert K, Gewirtz A, Madara JL, Serhan CN. Identification of a human enterocyte lipoxin A4 receptor that is regulated by interleukin (IL)-13 and interferon gamma and inhibits tumor necrosis factor alpha-induced IL-8 release. J Exp Med. 1998;187(8):1285-94. Epub 1998/05/23. PubMed PMID: 9547339.

227. Devchand PR, Arita M, Hong S, Bannenberg G, Moussignac RL, Gronert K, et al. Human ALX receptor regulates neutrophil recruitment in transgenic mice: roles in inflammation and host defense. Faseb J. 2003;17(6):652-9. PubMed PMID: 12665478.

228. Fukunaga K, Kohli P, Bonnans C, Fredenburgh LE, Levy BD. Cyclooxygenase 2 plays a pivotal role in the resolution of acute lung injury. J Immunol. 2005;174(8):5033-9. PubMed PMID: 15814734.

229. Levy BD, De Sanctis GT, Devchand PR, Kim E, Ackerman K, Schmidt BA, et al. Multi-pronged inhibition of airway hyper-responsiveness and inflammation by lipoxin A(4). Nat Med. 2002;8(9):1018-23. PubMed PMID: 12172542.

230. Paul-Clark MJ, Van Cao T, Moradi-Bidhendi N, Cooper D, Gilroy DW. 15-epilipoxin A4-mediated induction of nitric oxide explains how aspirin inhibits acute inflammation. J Exp Med. 2004;200(1):69-78. PubMed PMID: 15238606. 
231. Levy BD, Petasis NA, Serhan CN. Polyisoprenyl phosphates in intracellular signalling. Nature. 1997;389(6654):985-90. Epub 1997/11/14. doi: 10.1038/40180. PubMed PMID: 9353124.

232. Jozsef L, Zouki C, Petasis NA, Serhan CN, Filep JG. Lipoxin A4 and aspirin-triggered 15-epi-lipoxin A4 inhibit peroxynitrite formation, NF-kappa B and AP-1 activation, and IL-8 gene expression in human leukocytes. Proc Natl Acad Sci U S A. 2002;99(20):13266-71. PubMed PMID: 12235371.

233. Filep JG, Beauchamp M, Baron C, Paquette Y. Peroxynitrite mediates IL-8 gene expression and production in lipopolysaccharide-stimulated human whole blood. J Immunol. 1998;161(10):5656-62. Epub 1998/11/20. PubMed PMID: 9820546.

234. Zouki C, Jozsef L, Ouellet S, Paquette Y, Filep JG. Peroxynitrite mediates cytokineinduced IL-8 gene expression and production by human leukocytes. J Leukoc Biol. 2001;69(5):815-24. Epub 2001/05/19. PubMed PMID: 11358991.

235. Ohira T, Bannenberg G, Arita M, Takahashi M, Ge Q, Van Dyke TE, et al. A stable aspirin-triggered lipoxin A4 analog blocks phosphorylation of leukocyte-specific protein 1 in human neutrophils. J Immunol. 2004;173(3):2091-8. PubMed PMID: 15265945.

236. Badr KF, DeBoer DK, Schwartzberg M, Serhan CN. Lipoxin A4 antagonizes cellular and in vivo actions of leukotriene D4 in rat glomerular mesangial cells: evidence for competition at a common receptor. Proc Natl Acad Sci U S A. 1989;86(9):3438-42. Epub 1989/05/01. PubMed PMID: 2541448.

237. Fiore S, Romano M, Reardon EM, Serhan CN. Induction of functional lipoxin A4 receptors in HL-60 cells. Blood. 1993;81(12):3395-403. Epub 1993/06/15. PubMed PMID: 8389617. 
238. Aliberti J, Serhan C, Sher A. Parasite-induced lipoxin A4 is an endogenous regulator of IL-12 production and immunopathology in Toxoplasma gondii infection. J Exp Med. 2002;196(9):1253-62. PubMed PMID: 12417634.

239. Machado FS, Johndrow JE, Esper L, Dias A, Bafica A, Serhan CN, et al. Antiinflammatory actions of lipoxin A4 and aspirin-triggered lipoxin are SOCS-2 dependent. Nat Med. 2006;12(3):330-4. PubMed PMID: 16415877.

240. Schaldach CM, Riby J, Bjeldanes LF. Lipoxin A4: a new class of ligand for the Ah receptor. Biochemistry. 1999;38(23):7594-600. PubMed PMID: 10360957.

241. Maddox JF, Colgan SP, Clish CB, Petasis NA, Fokin VV, Serhan CN. Lipoxin B4 regulates human monocyte/neutrophil adherence and motility: design of stable lipoxin B4 analogs with increased biologic activity. Faseb J. 1998;12(6):487-94. PubMed PMID: 9535221.

242. Patcha V, Wigren J, Winberg ME, Rasmusson B, Li J, Sarndahl E. Differential insideout activation of beta2-integrins by leukotriene B4 and fMLP in human neutrophils. Exp Cell Res. 2004;300(2):308-19. Epub 2004/10/12. doi: S0014-4827(04)00389-1 [pii]

10.1016/j.yexcr.2004.07.015. PubMed PMID: 15474996.

243. Serhan CN, Takano T, Gronert K, Chiang N, Clish CB. Lipoxin and aspirin-triggered 15-epi-lipoxin cellular interactions anti-inflammatory lipid mediators. Clin Chem Lab Med. 1999;37(3):299-309. Epub 1999/06/03. doi: 10.1515/CCLM.1999.052. PubMed PMID: 10353476.

244. Soyombo O, Spur BW, Lee TH. Effects of lipoxin A4 on chemotaxis and degranulation of human eosinophils stimulated by platelet-activating factor and N-formyl-Lmethionyl-L-leucyl-L-phenylalanine. Allergy. 1994;49(4):230-4. Epub 1994/04/01. PubMed PMID: 8037356. 
245. Maddox JF, Serhan CN. Lipoxin A4 and B4 are potent stimuli for human monocyte migration and adhesion: selective inactivation by dehydrogenation and reduction. $\mathrm{J}$ Exp Med. 1996;183(1):137-46. PubMed PMID: 8551217.

246. Chiang N, Gronert K, Clish CB, O'Brien JA, Freeman MW, Serhan CN. Leukotriene B4 receptor transgenic mice reveal novel protective roles for lipoxins and aspirin-triggered lipoxins in reperfusion. J Clin Invest. 1999;104(3):309-16. PubMed PMID: 10430612.

247. Morris T, Stables M, Hobbs A, de Souza P, Colville-Nash P, Warner T, et al. Effects of low-dose aspirin on acute inflammatory responses in humans. $\mathbf{J}$ Immunol. 2009;183(3):2089-96. Epub 2009/07/15. doi: jimmunol.0900477 [pii]

10.4049/jimmunol.0900477. PubMed PMID: 19597002.

248. Morris T, Stables M, Colville-Nash P, Newson J, Bellingan G, de Souza PM, et al. Dichotomy in duration and severity of acute inflammatory responses in humans arising from differentially expressed proresolution pathways. Proc Natl Acad Sci U S A. 2010;107(19):8842-7. Epub 2010/04/28. doi: 1000373107 [pii]

10.1073/pnas.1000373107. PubMed PMID: 20421472.

249. Godson C, Mitchell S, Harvey K, Petasis NA, Hogg N, Brady HR. Cutting edge: lipoxins rapidly stimulate nonphlogistic phagocytosis of apoptotic neutrophils by monocytederived macrophages. J Immunol. 2000;164(4):1663-7. PubMed PMID: 10657608.

250. Maderna P, Cottell DC, Berlasconi G, Petasis NA, Brady HR, Godson C. Lipoxins induce actin reorganization in monocytes and macrophages but not in neutrophils: differential involvement of rho GTPases. Am J Pathol. 2002;160(6):2275-83. PubMed PMID: 12057930. 251. Bannenberg GL, Chiang N, Ariel A, Arita M, Tjonahen E, Gotlinger KH, et al. Molecular circuits of resolution: formation and actions of resolvins and protectins. J Immunol. 2005;174(7):4345-55. Epub 2005/03/22. doi: 174/7/4345 [pii]. PubMed PMID: 15778399. 
252. Freire-de-Lima CG, Xiao YQ, Gardai SJ, Bratton DL, Schiemann WP, Henson PM. Apoptotic cells, through transforming growth factor-beta, coordinately induce antiinflammatory and suppress pro-inflammatory eicosanoid and NO synthesis in murine macrophages. J Biol Chem. 2006;281(50):38376-84. Epub 2006/10/24. doi: M605146200 [pii]

10.1074/jbc.M605146200. PubMed PMID: 17056601.

253. Mitchell S, Thomas G, Harvey K, Cottell D, Reville K, Berlasconi G, et al. Lipoxins, aspirin-triggered epi-lipoxins, lipoxin stable analogues, and the resolution of inflammation: stimulation of macrophage phagocytosis of apoptotic neutrophils in vivo. J Am Soc Nephrol. 2002;13(10):2497-507. PubMed PMID: 12239238.

254. Leonard MO, Hannan K, Burne MJ, Lappin DW, Doran P, Coleman P, et al. 15-Epi16-(para-fluorophenoxy)-lipoxin A(4)-methyl ester, a synthetic analogue of 15-epi-lipoxin A(4), is protective in experimental ischemic acute renal failure. J Am Soc Nephrol. 2002;13(6):1657-62. PubMed PMID: 12039996.

255. McMahon B, Mitchell D, Shattock R, Martin F, Brady HR, Godson C. Lipoxin, leukotriene, and PDGF receptors cross-talk to regulate mesangial cell proliferation. FASEB J. 2002;16(13):1817-9. Epub 2002/09/12. doi: 10.1096/fj.02-0416fje

02-0416fje [pii]. PubMed PMID: 12223454.

256. Sato Y, Kitasato H, Murakami Y, Hashimoto A, Endo H, Kondo H, et al. Downregulation of lipoxin A4 receptor by thromboxane A2 signaling in RAW246.7 cells in vitro and bleomycin-induced lung fibrosis in vivo. Biomed Pharmacother. 2004;58(6-7):381-7. Epub 2004/07/24. doi: 10.1016/j.biopha.2004.05.006

S0753332204000873 [pii]. PubMed PMID: 15271420. 
257. Wu SH, Wu XH, Lu C, Dong L, Chen ZQ. Lipoxin A4 inhibits proliferation of human lung fibroblasts induced by connective tissue growth factor. Am J Respir Cell Mol Biol. 2006;34(1):65-72. Epub 2005/09/06. doi: 2005-0184OC [pii]

10.1165/rcmb.2005-0184OC. PubMed PMID: 16141446.

258. Serhan CN. Lipoxin biosynthesis and its impact in inflammatory and vascular events. Biochim Biophys Acta. 1994;1212(1):1-25. PubMed PMID: 8155718.

259. Tamaoki J, Tagaya E, Yamawaki I, Konno K. Lipoxin A4 inhibits cholinergic neurotransmission through nitric oxide generation in the rabbit trachea. Eur $\mathrm{J}$ Pharmacol. 1995;287(3):233-8. PubMed PMID: 8991795.

260. Hachicha M, Pouliot M, Petasis NA, Serhan CN. Lipoxin (LX)A4 and aspirintriggered 15-epi-LXA4 inhibit tumor necrosis factor 1alpha-initiated neutrophil responses and trafficking: regulators of a cytokine-chemokine axis. J Exp Med. 1999;189(12):1923-30. PubMed PMID: 10377187.

261. Pouliot M, Serhan CN. Lipoxin A4 and aspirin-triggered 15-epi-LXA4 inhibit tumor necrosis factor-alpha-initiated neutrophil responses and trafficking: novel regulators of a cytokine-chemokine axis relevant to periodontal diseases. J Periodontal Res. 1999;34(7):3703. Epub 2000/02/24. PubMed PMID: 10685363.

262. Machado FS, Johndrow JE, Esper L, Dias A, Bafica A, Serhan CN, et al. Antiinflammatory actions of lipoxin A(4) and aspirin-triggered lipoxin are SOCS-2 dependent. Nat Med. 2006;12(3):330-4. PubMed PMID: 16415877.

263. Munger KA, Montero A, Fukunaga M, Uda S, Yura T, Imai E, et al. Transfection of rat kidney with human 15-lipoxygenase suppresses inflammation and preserves function in experimental glomerulonephritis. Proc Natl Acad Sci U S A. 1999;96(23):13375-80. PubMed PMID: 10557328. 
264. O'Meara YM, Brady HR. Lipoxins, leukocyte recruitment and the resolution phase of acute glomerulonephritis. Kidney Int Suppl. 1997;58:S56-61. Epub 1997/03/01. PubMed PMID: 9067945.

265. Karp CL, Flick LM, Yang R, Uddin J, Petasis NA. Cystic fibrosis and lipoxins. Prostaglandins Leukot Essent Fatty Acids. 2005;73(3-4):263-70. Epub 2005/06/28. doi: S0952-3278(05)00093-1 [pii]

10.1016/j.plefa.2005.05.015. PubMed PMID: 15979866.

266. Pouliot M, Clish CB, Petasis NA, Van Dyke TE, Serhan CN. Lipoxin A(4) analogues inhibit leukocyte recruitment to Porphyromonas gingivalis: a role for cyclooxygenase-2 and lipoxins in periodontal disease. Biochemistry. 2000;39(16):4761-8. PubMed PMID: 10769133.

267. Levy BD, Bonnans C, Silverman ES, Palmer LJ, Marigowda G, Israel E. Diminished lipoxin biosynthesis in severe asthma. Am J Respir Crit Care Med. 2005;172(7):824-30. Epub 2005/06/18. doi: 200410-1413OC [pii]

10.1164/rccm.200410-1413OC. PubMed PMID: 15961693; PubMed Central PMCID: PMC2718403.

268. Gronert K, Maheshwari N, Khan N, Hassan IR, Dunn M, Laniado Schwartzman M. A role for the mouse 12/15-lipoxygenase pathway in promoting epithelial wound healing and host defense. J Biol Chem. 2005;280(15):15267-78. Epub 2005/02/15. doi: M410638200 [pii] 10.1074/jbc.M410638200. PubMed PMID: 15708862.

269. Schottelius AJ, Giesen C, Asadullah K, Fierro IM, Colgan SP, Bauman J, et al. An aspirin-triggered lipoxin A4 stable analog displays a unique topical anti-inflammatory profile. J Immunol. 2002;169(12):7063-70. PubMed PMID: 12471142. 
270. Aliberti J, Hieny S, Reis e Sousa C, Serhan CN, Sher A. Lipoxin-mediated inhibition of IL-12 production by DCs: a mechanism for regulation of microbial immunity. Nat Immunol. 2002;3(1):76-82. PubMed PMID: 11743584.

271. Bafica A, Scanga CA, Serhan C, Machado F, White S, Sher A, et al. Host control of Mycobacterium tuberculosis is regulated by 5-lipoxygenase-dependent lipoxin production. $\mathrm{J}$ Clin Invest. 2005;115(6):1601-6. Epub 2005/06/03. doi: 10.1172/JCI23949. PubMed PMID: 15931391; PubMed Central PMCID: PMC1136995.

272. Arita M, Yoshida M, Hong S, Tjonahen E, Glickman JN, Petasis NA, et al. Resolvin E1, an endogenous lipid mediator derived from omega-3 eicosapentaenoic acid, protects against 2,4,6-trinitrobenzene sulfonic acid-induced colitis. Proc Natl Acad Sci U S A. 2005;102(21):7671-6. PubMed PMID: 15890784.

273. Burr GO, Burr MM. Nutrition classics from The Journal of Biological Chemistry 82:345-67, 1929. A new deficiency disease produced by the rigid exclusion of fat from the diet. Nutr Rev. 1973;31(8):248-9. Epub 1973/08/01. PubMed PMID: 4586201.

274. Galli C, Rise P. Fish consumption, omega 3 fatty acids and cardiovascular disease. The science and the clinical trials. Nutr Health. 2009;20(1):11-20. Epub 2009/03/31. PubMed PMID: 19326716.

275. Riediger ND, Othman RA, Suh M, Moghadasian MH. A systemic review of the roles of n-3 fatty acids in health and disease. J Am Diet Assoc. 2009;109(4):668-79. Epub 2009/03/31. doi: S0002-8223(08)02335-3 [pii]

10.1016/j.jada.2008.12.022. PubMed PMID: 19328262.

276. Dietary supplementation with n-3 polyunsaturated fatty acids and vitamin E after myocardial infarction: results of the GISSI-Prevenzione trial. Gruppo Italiano per lo Studio 
della Sopravvivenza nell'Infarto miocardico. Lancet. 1999;354(9177):447-55. PubMed PMID: 10465168.

277. Leon H, Shibata MC, Sivakumaran S, Dorgan M, Chatterley T, Tsuyuki RT. Effect of fish oil on arrhythmias and mortality: systematic review. BMJ. 2008;337:a2931. Epub 2008/12/25. PubMed PMID: 19106137.

278. Ridker PM. The JUPITER trial: results, controversies, and implications for prevention. Circ Cardiovasc Qual Outcomes. 2009;2(3):279-85. Epub 2009/12/25. doi: 2/3/279 [pii]

10.1161/CIRCOUTCOMES.109.868299. PubMed PMID: 20031849.

279. De Caterina R, Caprioli R, Giannessi D, Sicari R, Galli C, Lazzerini G, et al. n-3 fatty acids reduce proteinuria in patients with chronic glomerular disease. Kidney Int. 1993;44(4):843-50. Epub 1993/10/01. PubMed PMID: 8258959.

280. Lu Y, Hong S, Tjonahen E, Serhan CN. Mediator-lipidomics: databases and search algorithms for PUFA-derived mediators. J Lipid Res. 2005;46(4):790-802. Epub 2005/02/22. doi: D400020-JLR200 [pii]

10.1194/jlr.D400020-JLR200. PubMed PMID: 15722568.

281. Serhan CN, Yang R, Martinod K, Kasuga K, Pillai PS, Porter TF, et al. Maresins: novel macrophage mediators with potent antiinflammatory and proresolving actions. J Exp Med. 2009;206(1):15-23. Epub 2008/12/24. doi: jem.20081880 [pii]

10.1084/jem.20081880. PubMed PMID: 19103881.

282. Serhan CN. Controlling the resolution of acute inflammation: a new genus of dual anti-inflammatory and proresolving mediators. J Periodontol. 2008;79(8 Suppl):1520-6. Epub 2008/09/04. doi: 10.1902/jop.2008.080231. PubMed PMID: 18673006. 
283. Serhan CN. Systems approach with inflammatory exudates uncovers novel antiinflammatory and pro-resolving mediators. Prostaglandins Leukot Essent Fatty Acids. 2008;79(3-5):157-63. Epub 2008/11/15. doi: S0952-3278(08)00131-2 [pii]

10.1016/j.plefa.2008.09.012. PubMed PMID: 19008087.

284. Arita M, Clish CB, Serhan CN. The contributions of aspirin and microbial oxygenase to the biosynthesis of anti-inflammatory resolvins: novel oxygenase products from omega-3 polyunsaturated fatty acids. Biochem Biophys Res Commun. 2005;338(1):149-57. Epub 2005/08/23. doi: 10.1016/j.bbrc.2005.07.181. PubMed PMID: 16112645.

285. Arita M, Bianchini F, Aliberti J, Sher A, Chiang N, Hong S, et al. Stereochemical assignment, antiinflammatory properties, and receptor for the omega-3 lipid mediator resolvin E1. J Exp Med. 2005;201(5):713-22. PubMed PMID: 15753205.

286. Serhan CN. Novel chemical mediators in the resolution of inflammation: resolvins and protectins. Anesthesiol Clin. 2006;24(2):341-64. Epub 2006/08/25. PubMed PMID: 16927933.

287. Campbell EL, Louis NA, Tomassetti SE, Canny GO, Arita M, Serhan CN, et al. Resolvin E1 promotes mucosal surface clearance of neutrophils: a new paradigm for inflammatory resolution. FASEB J. 2007;21(12):3162-70. Epub 2007/05/15. doi: 10.1096/fj.07-8473com. PubMed PMID: 17496159.

288. Gronert K, Kantarci A, Levy BD, Clish CB, Odparlik S, Hasturk H, et al. A molecular defect in intracellular lipid signaling in human neutrophils in localized aggressive periodontal tissue damage. J Immunol. 2004;172(3):1856-61. Epub 2004/01/22. PubMed PMID: 14734770.

289. Arita M, Ohira T, Sun YP, Elangovan S, Chiang N, Serhan CN. Resolvin E1 selectively interacts with leukotriene B4 receptor BLT1 and ChemR23 to regulate 
inflammation. J Immunol. 2007;178(6):3912-7. Epub 2007/03/07. doi: 178/6/3912 [pii]. PubMed PMID: 17339491.

290. Haworth O, Cernadas M, Yang R, Serhan CN, Levy BD. Resolvin E1 regulates interleukin 23, interferon-gamma and lipoxin A4 to promote the resolution of allergic airway inflammation. Nat Immunol. 2008;9(8):873-9. Epub 2008/06/24. doi: 10.1038/ni.1627. PubMed PMID: 18568027; PubMed Central PMCID: PMC2784998.

291. Schwab JM, Chiang N, Arita M, Serhan CN. Resolvin E1 and protectin D1 activate inflammation-resolution programmes. Nature. 2007;447(7146):869-74. Epub 2007/06/15. doi: nature05877 [pii]

10.1038/nature05877. PubMed PMID: 17568749.

292. Tjonahen E, Oh SF, Siegelman J, Elangovan S, Percarpio KB, Hong S, et al. Resolvin E2: identification and anti-inflammatory actions: pivotal role of human 5-lipoxygenase in resolvin E series biosynthesis. Chem Biol. 2006;13(11):1193-202. Epub 2006/11/23. doi: S1074-5521(06)00344-9 [pii]

10.1016/j.chembiol.2006.09.011. PubMed PMID: 17114001.

293. Dona M, Fredman G, Schwab JM, Chiang N, Arita M, Goodarzi A, et al. Resolvin E1, an EPA-derived mediator in whole blood, selectively counterregulates leukocytes and platelets. Blood. 2008;112(3):848-55. Epub 2008/05/16. doi: blood-2007-11-122598 [pii]

10.1182/blood-2007-11-122598. PubMed PMID: 18480426.

294. Hasturk H, Kantarci A, Ohira T, Arita M, Ebrahimi N, Chiang N, et al. RvE1 protects from local inflammation and osteoclast- mediated bone destruction in periodontitis. FASEB J. 2006;20(2):401-3. Epub 2005/12/24. doi: 10.1096/fj.05-4724fje. PubMed PMID: 16373400. 
295. Zabel BA, Ohyama T, Zuniga L, Kim JY, Johnston B, Allen SJ, et al. Chemokine-like receptor 1 expression by macrophages in vivo: regulation by TGF-beta and TLR ligands. Exp Hematol. 2006;34(8):1106-14. Epub 2006/07/26. doi: S0301-472X(06)00232-3 [pii]

10.1016/j.exphem.2006.03.011. PubMed PMID: 16863918.

296. Cash JL, Hart R, Russ A, Dixon JP, Colledge WH, Doran J, et al. Synthetic chemerinderived peptides suppress inflammation through ChemR23. J Exp Med. 2008;205(4):767-75. Epub 2008/04/09. doi: jem.20071601 [pii]

10.1084/jem.20071601. PubMed PMID: 18391062.

297. Krishnamoorthy S, Recchiuti A, Chiang N, Yacoubian S, Lee CH, Yang R, et al. Resolvin D1 binds human phagocytes with evidence for proresolving receptors. Proc Natl Acad Sci U S A.107(4):1660-5. Epub 2010/01/19. doi: 0907342107 [pii]

10.1073/pnas.0907342107. PubMed PMID: 20080636.

298. Spite M, Norling LV, Summers L, Yang R, Cooper D, Petasis NA, et al. Resolvin D2 is a potent regulator of leukocytes and controls microbial sepsis. Nature. 2009;461(7268):1287-91. Epub 2009/10/30. doi: nature08541 [pii]

10.1038/nature08541. PubMed PMID: 19865173.

299. Sun YP, Oh SF, Uddin J, Yang R, Gotlinger K, Campbell E, et al. Resolvin D1 and its aspirin-triggered 17R epimer. Stereochemical assignments, anti-inflammatory properties, and enzymatic inactivation. J Biol Chem. 2007;282(13):9323-34. Epub 2007/01/25. doi: M609212200 [pii]

10.1074/jbc.M609212200. PubMed PMID: 17244615.

300. Chiang N, Dalli J, Colas RA, Serhan CN. Identification of resolvin D2 receptor mediating resolution of infections and organ protection. J Exp Med. 2015;212(8):1203-17. 
doi: 10.1084/jem.20150225. PubMed PMID: 26195725; PubMed Central PMCID: PMCPMC4516788.

301. Duffield JS, Hong S, Vaidya VS, Lu Y, Fredman G, Serhan CN, et al. Resolvin D series and protectin D1 mitigate acute kidney injury. J Immunol. 2006;177(9):5902-11. Epub 2006/10/24. doi: 177/9/5902 [pii]. PubMed PMID: 17056514.

302. Levy BD, Kohli P, Gotlinger K, Haworth O, Hong S, Kazani S, et al. Protectin D1 is generated in asthma and dampens airway inflammation and hyperresponsiveness. J Immunol. 2007;178(1):496-502. Epub 2006/12/22. doi: 178/1/496 [pii]. PubMed PMID: 17182589.

303. Ariel A, Li PL, Wang W, Tang WX, Fredman G, Hong S, et al. The docosatriene protectin D1 is produced by TH2 skewing and promotes human T cell apoptosis via lipid raft clustering. J Biol Chem. 2005;280(52):43079-86. PubMed PMID: 16216871.

304. Mukherjee PK, Marcheselli VL, Barreiro S, Hu J, Bok D, Bazan NG. Neurotrophins enhance retinal pigment epithelial cell survival through neuroprotectin D1 signaling. Proc Natl Acad Sci U S A. 2007;104(32):13152-7. Epub 2007/08/03. doi: 0705949104 [pii]

\subsection{3/pnas.0705949104. PubMed PMID: 17670936.}

305. Mukherjee PK, Marcheselli VL, de Rivero Vaccari JC, Gordon WC, Jackson FE, Bazan NG. Photoreceptor outer segment phagocytosis attenuates oxidative stress-induced apoptosis with concomitant neuroprotectin D1 synthesis. Proc Natl Acad Sci U S A. 2007;104(32):13158-63. Epub 2007/08/03. doi: 0705963104 [pii]

10.1073/pnas.0705963104. PubMed PMID: 17670935.

306. Mukherjee PK, Marcheselli VL, Serhan CN, Bazan NG. Neuroprotectin D1: a docosahexaenoic acid-derived docosatriene protects human retinal pigment epithelial cells from oxidative stress. Proc Natl Acad Sci U S A. 2004;101(22):8491-6. Epub 2004/05/21. doi: 10.1073/pnas.0402531101 
0402531101 [pii]. PubMed PMID: 15152078; PubMed Central PMCID: PMC420421.

307. Lukiw WJ, Cui JG, Marcheselli VL, Bodker M, Botkjaer A, Gotlinger K, et al. A role for docosahexaenoic acid-derived neuroprotectin D1 in neural cell survival and Alzheimer disease. J Clin Invest. 2005;115(10):2774-83. Epub 2005/09/10. doi: 10.1172/JCI25420. PubMed PMID: 16151530; PubMed Central PMCID: PMC1199531.

308. Vedin I, Cederholm T, Freund Levi Y, Basun H, Garlind A, Faxen Irving G, et al. Effects of docosahexaenoic acid-rich n-3 fatty acid supplementation on cytokine release from blood mononuclear leukocytes: the OmegAD study. Am J Clin Nutr. 2008;87(6):1616-22. Epub 2008/06/11. doi: 87/6/1616 [pii]. PubMed PMID: 18541548.

309. Nelson DR, Koymans L, Kamataki T, Stegeman JJ, Feyereisen R, Waxman DJ, et al. P450 superfamily: update on new sequences, gene mapping, accession numbers and nomenclature. Pharmacogenetics. 1996;6(1):1-42. Epub 1996/02/01. PubMed PMID: 8845856.

310. Scarborough PE, Ma J, Qu W, Zeldin DC. P450 subfamily CYP2J and their role in the bioactivation of arachidonic acid in extrahepatic tissues. Drug Metab Rev. 1999;31(1):205-34. Epub 1999/03/05. doi: 10.1081/DMR-100101915. PubMed PMID: 10065373.

311. Roman RJ. P-450 metabolites of arachidonic acid in the control of cardiovascular function. Physiol Rev. 2002;82(1):131-85. Epub 2002/01/05. doi: 10.1152/physrev.00021.2001. PubMed PMID: 11773611.

312. Zhang Y, Oltman CL, Lu T, Lee HC, Dellsperger KC, VanRollins M. EET homologs potently dilate coronary microvessels and activate $\mathrm{BK}(\mathrm{Ca})$ channels. Am J Physiol Heart Circ Physiol. 2001;280(6):H2430-40. Epub 2001/05/18. PubMed PMID: 11356595.

313. Wang MH, Guan H, Nguyen X, Zand BA, Nasjletti A, Laniado-Schwartzman M. Contribution of cytochrome P-450 4A1 and 4A2 to vascular 20-hydroxyeicosatetraenoic acid 
synthesis in rat kidneys. Am J Physiol. 1999;276(2 Pt 2):F246-53. Epub 1999/02/10. PubMed PMID: 9950955.

314. Kikuchi Y, Miyauchi M, Oomori K, Kita T, Kizawa I, Kato K. Inhibition of human ovarian cancer cell growth in vitro and in nude mice by prostaglandin D2. Cancer Res. 1986;46(7):3364-6. Epub 1986/07/01. PubMed PMID: 3458525.

315. Bednar MM, Gross CE, Balazy MK, Belosludtsev Y, Colella DT, Falck JR, et al. 16(R)-hydroxy-5,8,11,14-eicosatetraenoic acid, a new arachidonate metabolite in human polymorphonuclear leukocytes. Biochem Pharmacol. 2000;60(3):447-55. Epub 2000/06/17. doi: S0006-2952(00)00345-2 [pii]. PubMed PMID: 10856441.

316. Fleming I. DiscrEET regulators of homeostasis: epoxyeicosatrienoic acids, cytochrome P450 epoxygenases and vascular inflammation. Trends Pharmacol Sci. 2007;28(9):448-52. Epub 2007/09/04. doi: S0165-6147(07)00188-5 [pii]

10.1016/j.tips.2007.08.002. PubMed PMID: 17764757.

317. Moreno JJ. New aspects of the role of hydroxyeicosatetraenoic acids in cell growth and cancer development. Biochem Pharmacol. 2009;77(1):1-10. Epub 2008/09/02. doi: S0006-2952(08)00521-2 [pii]

10.1016/j.bcp.2008.07.033. PubMed PMID: 18761324.

318. Spector AA, Norris AW. Action of epoxyeicosatrienoic acids on cellular function. Am J Physiol Cell Physiol. 2007;292(3):C996-1012. Epub 2006/09/22. doi: 00402.2006 [pii]

10.1152/ajpcell.00402.2006. PubMed PMID: 16987999.

319. Inceoglu B, Jinks SL, Ulu A, Hegedus CM, Georgi K, Schmelzer KR, et al. Soluble epoxide hydrolase and epoxyeicosatrienoic acids modulate two distinct analgesic pathways. Proc Natl Acad Sci U S A. 2008;105(48):18901-6. Epub 2008/11/26. doi: 0809765105 [pii] 
10.1073/pnas.0809765105. PubMed PMID: 19028872.

320. Inceoglu B, Schmelzer KR, Morisseau C, Jinks SL, Hammock BD. Soluble epoxide hydrolase inhibition reveals novel biological functions of epoxyeicosatrienoic acids (EETs). Prostaglandins Other Lipid Mediat. 2007;82(1-4):42-9. Epub 2006/12/14. doi: S10988823(06)00057-8 [pii]

10.1016/j.prostaglandins.2006.05.004. PubMed PMID: 17164131.

321. Node K, Huo Y, Ruan X, Yang B, Spiecker M, Ley K, et al. Anti-inflammatory properties of cytochrome P450 epoxygenase-derived eicosanoids. Science. 1999;285(5431):1276-9. Epub 1999/08/24. doi: 7768 [pii]. PubMed PMID: 10455056.

322. Liu Y, Zhang Y, Schmelzer K, Lee TS, Fang X, Zhu Y, et al. The antiinflammatory effect of laminar flow: the role of PPARgamma, epoxyeicosatrienoic acids, and soluble epoxide hydrolase. Proc Natl Acad Sci U S A. 2005;102(46):16747-52. Epub 2005/11/04. doi: 0508081102 [pii]

10.1073/pnas.0508081102. PubMed PMID: 16267130.

323. Briggs WH, Xiao H, Parkin KL, Shen C, Goldman IL. Differential inhibition of human platelet aggregation by selected Allium thiosulfinates. J Agric Food Chem. 2000;48(11):5731-5. Epub 2000/11/23. doi: jf0004412 [pii]. PubMed PMID: 11087546.

324. Fitzpatrick FA, Ennis MD, Baze ME, Wynalda MA, McGee JE, Liggett WF. Inhibition of cyclooxygenase activity and platelet aggregation by epoxyeicosatrienoic acids. Influence of stereochemistry. J Biol Chem. 1986;261(32):15334-8. Epub 1986/11/15. PubMed PMID: 3095326.

325. Heizer ML, McKinney JS, Ellis EF. 14,15-Epoxyeicosatrienoic acid inhibits platelet aggregation in mouse cerebral arterioles. Stroke. 1991;22(11):1389-93. Epub 1991/11/01. PubMed PMID: 1750047. 
326. Node K, Ruan XL, Dai J, Yang SX, Graham L, Zeldin DC, et al. Activation of Galpha $\mathrm{s}$ mediates induction of tissue-type plasminogen activator gene transcription by epoxyeicosatrienoic acids. J Biol Chem. 2001;276(19):15983-9. Epub 2001/03/30. doi: 10.1074/jbc.M100439200

M100439200 [pii]. PubMed PMID: 11279071.

327. Behm DJ, Ogbonna A, Wu C, Burns-Kurtis CL, Douglas SA. Epoxyeicosatrienoic acids function as selective, endogenous antagonists of native thromboxane receptors: identification of a novel mechanism of vasodilation. J Pharmacol Exp Ther. 2009;328(1):2319. Epub 2008/10/07. doi: jpet.108.145102 [pii]

10.1124/jpet.108.145102. PubMed PMID: 18836067.

328. Hill E, Fitzpatrick F, Murphy RC. Biological activity and metabolism of 20hydroxyeicosatetraenoic acid in the human platelet. Br J Pharmacol. 1992;106(2):267-74. Epub 1992/06/01. PubMed PMID: 1327375.

329. Buckley CD, Gilroy DW, Serhan CN, Stockinger B, Tak PP. The resolution of inflammation. Nat Rev Immunol. 2013;13(1):59-66. Epub 2012/12/01. doi: 10.1038/nri3362. PubMed PMID: 23197111.

330. Serhan CN, Brain SD, Buckley CD, Gilroy DW, Haslett C, O'Neill LA, et al. Resolution of inflammation: state of the art, definitions and terms. FASEB J. 2007;21(2):32532. Epub 2007/02/03. doi: 10.1096/fj.06-7227rev. PubMed PMID: 17267386; PubMed Central PMCID: PMC3119634.

331. Kurzrok R, Lieb CC. Biochemical studies of human semen. II. The action of semen on the human uterus. Proc Soc Exp Biol Med. 1930;28:268-72. 